Published in final edited form as:

Microbiol Spectr. 2017 January ; 5(1): . doi:10.1128/microbiolspec.MCHD-0049-2016.

\title{
Inflammasomes in Myeloid Cells: Warriors within
}

\author{
Sushmita Jha ${ }^{1}$, W. June Brickey ${ }^{2}$, and Jenny Pan-Yun Ting ${ }^{2}$ \\ ${ }^{1}$ Department of Biology, Indian Institute of Technology Jodhpur, Rajasthan, 342011, India \\ ${ }^{2}$ Lineberger Comprehensive Cancer Center, Department of Genetics, The University of North \\ Carolina, Chapel Hill, North Carolina 27599-7295, USA
}

\section{Abstract}

The inflammasome is a large multimeric protein complex comprised of an effector protein that demonstrates a specificity for a variety of activators or ligands, an adaptor molecule and procaspase-1 which is converted to caspase-1 upon inflammasome activation. Inflammasomes are expressed primarily by myeloid cells and are located within the cell. The macromolecular inflammasome structure can be visualized by cryo-electron microscopy. This complex has been found to play a role in a variety of disease models in mice and several have been genetically linked to human diseases. In most cases, the effector protein is a member of the NLR (nucleotide-binding domain leucine rich repeat containing), or NOD (nucleotide oligomerization domain)-like receptor protein family. However, other effectors have also been described, with the most notable being AIM2 (absence in melanoma 2), which recognizes DNA to elicit inflammasome function. This chapter will focus on the role of the inflammasome in myeloid cells and its role in health and disease.

\section{Introduction}

Inflammation is the body's response to injury, pathogen exposure and irritants. Pattern recognition receptors allow our body to recognize a diverse array of patterns generated during exposure to these insults. In 2002, the Nucleotide-binding domain, Leucine-rich Repeat containing (NLR, also known as NOD-like receptor) gene family of pattern recognition receptors was discovered(1-3). While several members were already recognized at that point, reports of the entire NLR family provided a global view. In the past fifteen years of research, the physiological relevance of these genes has been revealed to include a diverse variety of functions. Gene mutations in some of the family members have been linked to autoinflammatory diseases in humans (Figure 1). This association of mutations in NLR genes to autoinflammatory diseases indicates critical functions in the regulation of immunity and inflammation.

There are 22 NLR genes in humans and 34 identified in mice, with each gene encoding a protein with a characteristic tripartite structure of central nucleotide binding domain (NBD), an $\mathrm{N}$-terminal effector domain and a variable number of $\mathrm{C}$-terminal leucine rich repeats (LRRs) (Figure 2)(4). Proteins with domain architecture similar to that of human NLRs exist in plants and in invertebrates such as sea urchins. These proteins are absent in nematodes and Drosophila, suggesting either convergent evolution between mammalian and plant NLRs or loss in invertebrates $(5,6)$. The effector domains of NLRs can be combinations of the 
following domain types: acidic transactivation domain (AD), baculoviral inhibitory repeat (BIR)-like domain, caspase recruitment domain (CARD), pyrin domain or domain of unknown function (X) (Figure 2). The length of the LRR domains is highly variable. For example, an NLR may contain up to 30+ LRR domains(7). While each NLR has a unique capability to sense a variety of pathogen-associated molecular patterns (PAMPs) and dangerassociated molecular patterns (DAMPs), the exact mechanisms of NLR-ligand binding have only recently emerged for NOD2 and NLRC4/NAIP proteins. Initially NLRs were presumed to be expressed only in innate immune cells of monocyte/macrophage lineage. However, their ubiquitous expression throughout the human body is now widely accepted.

Interestingly, different NLRs show distinct tissue, cellular and intracellular distributions, suggesting variable roles in different cell types(8). This chapter will focus on the role of NLRs in myeloid cells in the normal host as well as in dysregulated immune states of disease.

\section{Activation of Inflammasome NLRs}

Upon activation, several NLRs form multiprotein complexes called "inflammasomes". These complexes consist of an NLR, an adapter molecule known as ASC (apoptosis-associated speck-like protein containing a CARD) and the inflammatory protease pro-caspase-1 ${ }^{4-5}$. Even though the inflammasome mediated roles of NLRs have been extensively studied, there are several non-inflammasome mediated functions of NLRs including NF- $\kappa B$ regulation, MAPK activation, cytokine and chemokine production, IFN production, ribonuclease $\mathrm{L}$ activation and antimicrobial reactive oxygen species (ROS) production. The inflammasome forming NLRs will be discussed in detail here, while the readers are referred to other reviews for descriptions of the non-inflammasome forming NLRs(9-11).

A subset of NLRs (NLRP1, NLRP3, NLRP6, NLRP7, NLRC4, NLRC5 and NAIP2/5/6) has been reported to form inflammasomes. Each NLR with its activating signal, inflammasome components and disease association will be described here in some detail.

\section{NLRP1}

NLR family, Pyrin domain containing 1 or NLRP1 (formerly CARD7, DEFCAP, NALP1) was first characterized as a member of the CED-4 family of apoptotic proteins that are required to initiate programmed cell death(12-14). The first caspase-1 activating inflammasome to be identified consisted of NLRP1, ASC, caspase-1 and caspase-5(15). Overexpression of NLRP1 in mammalian cells led to apoptosis $(12,13)$. NLRP1 is a cytoplasmic protein that is highly expressed in peripheral blood lymphocytes(12). Initial studies on NLRP1 suggested that the NLRP1 inflammasome in humans consists of NLRP1, pro-caspase-1, caspase-5 and the adapter ASC $(12,13)$. It was later revealed that even though the presence of ASC may not be required for processing of pro-caspase-1 by the NLRP1 inflammasome, ASC does augment processing of pro-caspase-1(16).

There is one NLRP1 gene in humans in contrast to three paralogs in mice, Nlrp1a, Nlrp1b, NIrp1c(17). Interestingly, not all strains of mice express all isoforms. For example, some strains of inbred mice express different splice variants of NIrp1b, while NIrp1a is highly conserved(18). The NLRP1 protein in humans consists of an N terminal pyrin domain, a 
central NBD-associated domain (NAD), LRRs, a function to find (FIIND) domain, and a C terminal CARD domain. Polymorphisms in the NLRP1 gene, in both the noncoding and coding sequences have been associated with the dermatologic autoimmune disease vitiligo(19-21). The NLRP1 haplotype associated with vitiligo and other autoimmune disorders leads to increased IL- $1 \beta$ processing. Several coding polymorphisms have also been associated with heightened risk for other autoimmune diseases such as Addison's disease and type 1 diabetes(22).

The mouse Nlrp1 paralogs vary in structure from the human protein such that Nlrp1a lacks the $\mathrm{N}$ terminal pyrin domain, Nlrp1b lacks both the pyrin and NAD domains and Nlrp1c lacks all but the NBD and LRR domains. Due to these differences, mouse and human NLRP1 appear to exhibit functional differences. Specifically, susceptible and resistant mouse Nlrp1b loci were genetically associated with Bacillus anthracis susceptibility $(23,24)$. Additionally, anthrax lethal toxin was found to activate mouse Nlrp1b and rat Nlrp1 inflammasome(25), resulting in caspase-1-dependent pyroptosis. Lethal toxin is composed of two proteins: protective antigen (PA) and lethal factor (LF), with PA binding to anthrax toxin receptors on host cells and subsequently translocating LF into the cytosol(26). LF was found to cause the proteolytic cleavage of rat Nlrp1 at the N-terminus, presumably by cleaving an inhibitory domain. Mutation of this cleavage site transformed a responsive allele to a nonresponsive allele and resulted in the abrogation of caspase-1 activation(27). In the mouse system, an engineered Nlrp1b that contained an artificial TEV protease cleavage site activated inflammasome in the presence of TEV(26). Interestingly, this cleavage site coincided with the cleavage site found in rat NLRP1, although dissimilar in sequence. Overall, this association of LF cleavage of Nlrp1b in the intact animal is less straightforward, in that Nlrp1b protein from both LF-responsive and - nonresponsive mouse strains were cleaved by $\operatorname{LF}(28)$.

In addition to pathogens, human NLRP1 inflammasome is activated by the peptidoglycan component muramyl dipeptide (MDP)(16). MDP stimulation of a macrophage cell line also leads to association of overexpressed NLRP1 with NOD2, leading to formation of a multiprotein complex consisting of NLRP1, NOD2 and caspase-1(25). These results suggest either the existence of an inflammasome containing NLRP1 plus NOD2 that is activated by MDP, or that MDP activates both NLRP1 and NOD2 inflammasomes. However, a mouse cell line deficient in NIrp1b and lacking inflammasome activation by anthrax lethal toxin shows no defect in the assembly of NLRP1 inflammasome by MDP(29). While investigating the crystal structure of the LRR domain of NLRP1, Reubold et al. concluded that the LRR domain is not likely to contain the MDP-binding domain(30). Thus MDP may represent a species specific activator of NLRP1, considering the structural difference between human and rodent NLRP1.

NLRP1 has also been shown to mediate inflammasome activation in response to Toxoplasma gondii in a human monocytic cell line(31). This protein was later found to mediate host response to Toxoplasma in mice(32) but the process was not dependent on the cleavage site of Nlrp1b found in anthrax(23). Both Nlrp1b and Nlrp3 form inflammasomes that restrict Toxoplasma gondii infection via the production of IL-18(33). Finally, additional studies have 
demonstrated that mouse Nlrpla mediates inflammasome and pyroptosis function during LCMV infection and upon chemotherapy treatment(34).

Aside from response to microbial pathogen, NLRP1 is associated with several disease pathologies, including acute glaucoma, traumatic brain injury, acute lung injury, colitis and colitis-associated tumorigenesis(29, 35-37). Interestingly, a recent paper showed that Nlrp1 is also involved in metabolic disease, where it prevents obesity by the production of IL-18 which is known to prevent overeating(38). An inflammasome consisting of NLRP1, ASC, caspase-1, caspase-11 (the rodent ortholog of human caspase-5) and the X-linked inhibitor of apoptosis protein (XIAP) was shown to be present in rat spinal cord motor neurons, in protein co-immunoprecipitation and immunofluorescence experiments(39). Remarkably, therapeutic neutralization of ASC with an antibody was shown to improve histopathology after traumatic brain injury via reduction of immune responses(40). This finding is consistent with a report that ASC specks accumulate in the extracellular space after cells undergo pyroptosis to promote IL-1 $\beta$ maturation. Although phagocytosis of these specks was shown to induce lysosomal damage, stimulate soluble ASC nucleation and increase inflammation(41), "frustrated" phagocytosis has been noted as a consequence to injury (and inflammasome activation) found in various organs.

\section{NLRP3}

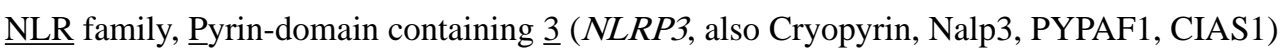
was discovered in 2001, in a seminal report that mapped a causative NLRP3 mutation to rheumatologic autoinflammatory disorders, namely familial cold autoinflammatory syndrome (FCAS) and Muckle Wells syndrome (MWS)(42). In 2002, with the discovery of NOMID/CINCA (neonatal-onset multisystem inflammatory disease and Chronic infantile neurologic cutaneous and articular syndrome), FCAS and MWS were classified along with NOMID to form the cold associated periodic syndromes (CAPS) $(43,44)$. To date, the primary focus of inflammasome research has been anchored by NLRP3, which is a cytoplasmic protein that is primarily expressed in monocytes, macrophages, granulocytes, dendritic cells, epithelial cells and osteoblasts $(45,46)$. NLRP3 expression in myeloid cells is highly inducible(47). The protein is composed of 3 distinct domains: the $\mathrm{N}$ terminal pyrin domain, the central nucleotide binding domain (NBD), and the $\mathrm{C}$ terminal leucine-rich repeats (LRRs).

NLRP3 responds to a wide range of DAMPs and PAMPs, including bacterial and viral nucleic acids(48, 49), intracellular pathogens; $\operatorname{ATP}(50)$, uric acid(51, 52), $\beta$-amyloid(53), hyaluronan and heparin sulfate(54); silica(55-57), asbestos(56), cholesterol $(58,59)$ and alum crystals $(57,60)$; metabolites associated with type 2 diabetes such as ceramide, saturated fatty acids, islet amyloid peptides(61-63); hemozoin(64) byproduct from bloodfeeding parasites that cause malaria; and cyclic dinucleotides (65). Activation of the NLRP3 inflammasome requires two signals and is controlled at transcriptional and post-translational levels (Figure 3). The first signal, also referred to as the priming signal, is the induction of the toll-like receptor (TLR)/nuclear factor (NF)- $\kappa$ B pathway to upregulate the expression of NLRP3(50)and pro-IL-1 $\beta(66)$. Signal 2 is transduced by various PAMPs and DAMPs to activate the functional NLRP3 inflammasome by initiating assembly of a multi-protein 
complex consisting of NLRP3, the adaptor protein ASC, and pro-caspase-1(67). Association of NLRP3 with ASC is required for recruitment of pro-caspase-1(68). ASC utilizes its CARD domain to recruit pro-caspase-1 via homotypic CARD-CARD interactions. In the inflammasome complex, the inactive pro-caspase-1 undergoes autocatalytic cleavage to form active caspase-1. Caspase-1 in turn can cleave and activate multiple substrates ranging from chaperones, cytoskeletal and translation machinery, glycolysis and immune proteins such as the proinflammatory cytokines IL-1 $\beta$ and IL-18(69-71). While NLRP3 is known to respond to several PAMPs and DAMPs, evidence for direct binding of any ligand to NLRP3 remains indeterminate. One model is that NLRP3 activation is mediated via secondary intermediates such as potassium efflux(50), change in cell volume(72), calcium mobilization via the calcium channels TRPM2 or CASR(73-75), osmolarity changes(76), reactive oxygen species $(\mathrm{ROS})(77)$ or mitochondrial DNA release $(78,79)$.

NLRP3 is associated with autoinflammatory, metabolic and autoimmune diseases(80$84)^{80-84}$. Autoinflammatory diseases will be discussed here. Autosomal dominant mutations in NLRP3 lead to three CAPS autoinflammatory syndromes in humans, ranging from the mild FCAS, to the intermediate MWS and the more severe NOMID/CINCA syndromes. Fever, urticaria-like rash and varying degrees of arthropathy and neurological manifestations are present in all three syndromes(43, 85-87). FCAS consists of the mildest symptoms including cold-induced urticaria and mild arthralgia. MWS is intermediate with non-cold induced spontaneous urticaria, sensorineural hearing loss, arthralgia, and in some cases renal amyloidosis. CINCA is the most severe with spontaneous urticaria, deforming arthropathy, sensorineural hearing loss, and chronic aseptic meningitis. All CAPS are characterized by increased levels of IL-1 $\beta$ in the absence of infection and can be successfully treated with inhibitors of IL-1 $\beta(88-90)$. Gain-of-function mutations of NLRP3 enhance IL- $1 \beta$ secretion even in the absence of a stimulus in vitro(15).

Major advances regarding NLRP3 inflammasome formation have been gleaned from elegant biochemical and cryo-electron microscopy (EM) studies. Biochemical studies showed that the pyrin domain is an evolutionary conserved structure that can cause ASC to form a prionlike filament, which then activates downstream effector caspases. Cryo-EM(91) results similarly support a model in which activated NLRP3 forms an oligomeric platform where the pyrin domain nucleates ASC via the latter's pyrin domain to form a filamentous structure. The CARD domain of ASC then interacts with the CARD domain of caspase-1 causing proximal caspase-1 to undergo auto-cleavage(92). As is noted below, in addition to NLRP3, AIM2 inflammasome activation by DNA binding also undergoes the same process.

\section{NLRC4 and NAIP}

NLR family, $\underline{\text { Caspase }}$ Recruitment domain containing 4 (NLRC4, also IPAF) is coupled to NAIP proteins (see later) that act as cytosolic receptors for PAMPs produced by flagellated pathogens, such as Salmonella typhimurium $(68,93)$ and Legionella pneumophila(94), and non-flagellated pathogens, such as Shigella flexneri and Pseudomonas aeruginosa(95).

NLRC4 forms a homo-oligomeric inflammasome with caspase-1(68). The crystal structure of NLRC4 suggested that it remains in an autoinhibited state when unstimulated with ADP 
bound to its central NBD. Disruption of this ADP-NBD interaction leads to constitutive activation of NLRC4(96).

NLRC4 is highly expressed in human brain, bone marrow and the THP-1 human monocytic cell line(97). Initial characterization of NLRC4 in human tissues and cell lines demonstrated its direct association with the CARD domain of pro-caspase-1 through CARD-CARD interactions $(97,98)$. This interaction can cause autocatalytic processing of pro-caspase-1 to caspase-1(97). A constitutively active NLRC4 causes autocatalytic processing of procaspase-1, generating caspase-1-dependent apoptosis in transfected cells(97). In macrophages, activation of the NLRC4 inflammasome by cytoplasmic flagellin leads to caspase- 1 activation and IL- $1 \beta$ release $(68,93,99)$. It is expected that NLRC4 interacts directly with pro-caspase-1 through CARD-CARD interactions. Although direct interaction of ASC with NLRC4 has not yet been demonstrated, Asc-deficient macrophages show defective caspase- 1 activation and IL-1 $\beta$ release in response to Salmonella, Shigella and Pseudomonas infections, indicating that ASC can enhance the function of NLRC4(68, 95, 100).

NLR apoptosis-inhibitory proteins (NAIP, formerly called BIRC1, NLRB1) represent prime examples of NLRs that recognize their cognate ligands, which promotes NLRC4 recruitment to form a multimeric inflammasome complex(101-103). NAIP is expressed in peripheral blood mononuclear cells and macrophages. While the human genome has one NAIP gene that is functionally similar to murine Naip1(101, 104), there are 7 paralogs of NAIP in mice (Naip1-7), presumably to provide specificity of binding to a number of bacterial ligands.

Based on co-immunoprecipitation studies utilizing over-expressed NAIP and NLRC4, these two proteins were shown to associate, suggesting the potential for co-engagement in the same caspase-1 activating inflammasome(105). NAIP5 inflammasome activation has been reported in response to the C-terminus of flagellin after Legionella pneumophila infection(106). Transduction of macrophages with the C-terminal 35 amino acid fragment of flagellin leads to NAIP5-dependent cell death, while full length flagellin induces NAIP5independent, NLRC4-dependent cell death and IL-1 $\beta$ release. Since NAIP5 does not have a caspase domain, it requires NLRC4 to activate pro-caspase-1. This suggests a mechanism for differential sensing of bacterial components where NAIP5 appears to possess NLRC4dependent and -independent functions(106).

A recent study by Tenthorey et al. utilized a panel of chimeric NAIP molecules and identified the central NBD domain, rather than the expected LRR domain, to be associated with bacterial ligand binding(107). Moreover, ligand binding is essential for oligomerization of NAIP monomers into an inflammasome. In addition to NAIP5, NAIP6 can also recognize flagellin(102). In contrast, NAIP1 and 2 recognize bacterial type 3 secretory system needle protein and rod protein, respectively, but do not recognize flagellin. As a genetic test, mice with specific deletions in Naip1 and Naip2 provided biologic evidence for this specificity in mediating bacterial clearance(102, 108, 109).

Similar to NLRP3 and AIM2 (see below), cryo-EM has shed light on the assembly of the NLRC4/NAIP inflammasome. A contrasting model has emerged where ligand (PrgJ)-bound 
NAIP is the initiating effector, but only one activated NAIP2 is necessary to cause the activation of NLRC4 protein that undergoes a dramatic conformational change in the exposure of its catalytic surface to activate another NLRC4, eventually forming a wheel-like configuration. This wheel-like platform associates with caspase-1 to cause the autocatalytic cleavage of caspase-1(110-112). In this model, ASC does not play a role since the CARDCARD domain interaction necessary for the final activation step is mediated through NLRC4 and caspase-1.

NAIP and NLRC4 also have roles that are distinct from the inflammasome and myeloid cells. For example, epithelium-intrinsic functions of this protein pair are associated with restriction of Salmonella proliferation in the gut epithelium, independent of inflammasome products(113). NAIP/NLRC4 is also known to inhibit caspase-3 and caspase-7 mediated pathways(114). NAIP interacts with pro-caspase-9 via its BIR3 domain. This association prevents the autoproteolysis of caspase-9 in the apoptosome complex, preventing caspase-9mediated cell death(115). The NBD and BIR domains of NAIP are required for inhibition of pro-caspase-9 autoproteolysis. Human NAIP is involved in bacterial sensing and inducing pyroptosis in human macrophages and epithelial cells(116).

In 1995, two groups reported deletion mutants of the Naip gene in patients with spinal muscular atrophy $(117,118)$. Since then, multiple reports in a number of countries have shown that deletions in Naip represent one of the most frequent and consistent genomic changes associated with spinal muscular dystrophy and positively correlates with clinical severity of this disease(119). The molecular basis for this disease association remains to be elucidated. More recently, a mutation in the NBD domain in NLRC4 was described that causes a gain-of-function phenotype that increases inflammasome activation and recurrent macrophage activation syndrome(120).

\section{NLRP6}

NLRP6 (formerly, PYPAF5) plays a role in impeding clearance of both Gram positive and negative bacterial infections. Overexpression of ASC with NLRP6 leads to enhanced caspase-1 activation(121), suggesting that it serves an inflammasome function. Structurally, NLRP6 resembles NLRP3, with an N-terminal pyrin domain, a central NOD domain and Cterminal LRRs. NLRP6 is expressed in myeloid cells such as granulocytes, dendritic cells and macrophages; is found in CD4 and CD8 T cells(122-126); and is activated during development by PPAR- $\gamma$ in intestinal epithelium(127).

The majority of studies have found that NLRP6 protects against experimental colitis and colitis-associated tumorigenesis $(125,128)$ and its function in monocytes contributes to this protective outcome(129). However, divergent mechanisms have been proposed to account for this activity. An analysis of the association between NLRP6 and the microbiome suggests that NIrp6 deletion in mice causes dysbiosis attributed to reduced IL-18 which then causes expanded pathobiont bacteria Bacteroides (Prevotellaceae) and TM7 microbiota(128). Reciprocally, the presence of the microbiota enhances caspase-1 maturation that is dependent on NLRP6 control(130). However, other reports indicate alternative roles for NLRP6. It has been implicated in the control of intestinal epithelium renewal(126) to preserve the epithelial barrier as a checkpoint regulator of NF- $\mathrm{KB} / \mathrm{MAPK}$ 
pathways(124) or as a positive regulator of interferon-induced responses (i.e. ISGs) during viral infection(131). In addition, NLRP6 deficiency has been found to cause defective autophagy in goblet cells and reduced mucus secretion, thus impeding pathogen clearance(132). A separate report also showed a similar dependency of goblet cell mucus secretion on NLRP6 and caspase-1/11, but not on IL-1/IL-18(133). Precisely how caspase-1/11 are involved is unclear.

\section{NLRC5, NLRP7 and NLRP12}

NLRC5, NLRP7 and NLRP12 represent three NLRs which have other functions, but also have been reported to mediate inflammasome function. While the reported function of NLRC5 is to regulate class I MHC gene transcription, studies in human macrophage lines or primary monocytic cells indicated that it also mediates inflammasome activation in a similar fashion as NLRP3 and associates with NLRP3(7). Similarly, rhinovirus induces NLRP3- and NLRC5-dependent inflammasome activation in bronchial cells(134). In NIrc5 deficient mice, Nlrp3 inflammasome is partially impaired, hinting at the intersection of these two factors(135).

NLRP7 consists of an N-terminal pyrin domain, followed by a NBD domain and C-terminal LRRs. Structural analysis of the pyrin domain from NLRP7 indicated that it possesses a six a-helix bundle death domain fold and forms a strong hydrophobic cluster upon pyrin-pyrin interactions(136). Khare et al. demonstrated the formation of a NLRP7-containing inflammasome in response to microbial lipopeptides in human macrophages(137). Activation of NLRP7 promoted ASC-dependent caspase-1 activation, IL-1 $\beta$ and IL-18 maturation and restriction of intracellular bacterial replication, but not caspase-1independent secretion of the pro-inflammatory cytokines IL- 6 and tumor necrosis factor- $a$. Radian et al. utilized the THP-1 monocytic cell line expressing a mutated Walker A motif to show defective NLRP7 inflammasome activation, thus suggesting that the NBD of NLRP7 is responsible for ATP binding and ATPase activity(138). This mutant cell line also showed defective IL- $1 \beta$ release and pyroptosis in response to acylated lipopeptides and $S$. aureus infection.

NLRP7 also has alternate functions outside of myeloid cells and is highly expressed in MI and MII oocytes. Mutations in the maternal gene Nlrp 7 are associated with biparental hydatidiform mole (HYDM1) in a number of patient cohorts which is characterized by abnormal growth of the placenta and lack of proper embryonic development(139). To identify the molecular mechanism associated with HYDM1, Singer et al. utilized a yeast two-hybrid screen against an ovarian library with NLRP7 as the bait. This approach led to the identification of the transcriptional repressor ZBTB16 as an interacting protein of NLRP7(140). This interaction was further verified in mammalian cells by immunoprecipitation and confocal microscopy; however, a clear mechanism for the molecular events leading to HYDM1 remains unknown.

NLRP12 (formerly called Monarch, PYPAF7, CLR19.3) was one of the first NLRs reported to be a negative regulator of inflammation via suppression of NF- $\mathrm{KB}$ signaling $(141,142)$. NLRP12 protein consists of an N-terminal pyrin domain, a central NBD, and a C-terminal domain composed of at least 12 LRRs(143). Initial studies of NLRP12 utilizing 
overexpression systems suggested that it forms an inflammasome with ASC $(144,145)$.

Additional research points to selective activation of the NLRP12 inflammasome by malaria and Yersinia(146, 147). However, aside from inflammasome activation, NLRP12 has prominent functions associated with inhibition of cytokine and inflammatory responses. At one level it induces proteasome-mediated degradation of NF- $\mathrm{kB}$ inducing kinase (NIK), leading to the suppression of the non-canonical NF- $\mathrm{\kappa B}$ pathway and reduced expression of p52-dependent genes $C c r 4, C x c 112$ and $C x c 113(141)$. Two reports confirmed these data by using NIrp12-/- mice in the azoxymethane chemically-induced colorectal cancer model with the inflammatory agent dextran sodium sulfate (AOM-DSS). These reports congruently found that ablation of NLRP12 increases NF- $\mathrm{BB}$ canonical and non-canonical pathways, increases ERK phosphorylation in innate immune cells as well as in non-hematopoietic cells in the tumor model, and enhances proinflammatory cytokines and chemokines typically known to promote tumorigenesis(148),(149). NLRP12 also attenuates host response to Salmonella(150); however, this activity may be pathogen specific, in that $N I r p 12^{-/}$mice exhibited normal host response to other bacteria(151).

Mutations in NIrp12 lead to Guadeloupe Variant Periodic Fever Syndrome. In this syndrome, the following alterations were identified: two missense mutations within the Nlrp12 gene, nonsense mutation causing truncation within the NBD domain of the protein and deletion mutation leading to loss of the C-terminal LRRs. Both missense mutations caused reduced activity in the suppression of NF- $\mathrm{kB}$ signaling by NLRP12, while the NBD mutation caused a more significant impact on normal NLRP12-induced NF- $\kappa B$ signaling as compared to the LRR mutation. Since the symptoms are similar to FCAS, this syndrome is referred to as FCAS2. Individuals with this syndrome present with cold-induced heterogeneous symptoms including fever, arthralgia, myalgia, sensorineural hearing loss, aphthous ulcers and lymphadenopathy(152).

\section{AIM2}

In addition to inflammasome NLRs, AIM2 (Absent in Melanoma 2) is a DNA sensor that activates the inflammasome(153-156). AIM2, an interferon-inducible gene also known as PYHIN4, was identified while screening tumor suppressor genes associated with melanoma(157). The AIM2 protein consists of an N-terminal pyrin domain, mediating homotypic interactions with ASC, and a C-terminal HIN-200 domain for DNA binding. AIM2 can associate into ASC specks to form a novel inflammasome platform inducing activation of ASC-mediated apoptotic and pyroptotic cell death pathways during host response to bacterial DNA such as from F. tularensis(153, 155, 157-159).

The crystal structure characterization of AIM2 has provided insight into interactions important for AIM2 auto-inhibition and inflammasome assembly(160). AIM2 inflammasome-mediated and non-classical IL- $1 \beta$ secretion induced by LC-3 autophagy are linked via the microtubule-associated protein EB-1(161). AIM2 provides host defense against both cytosolic bacterial and viral pathogens, such as Francisella tularensis, Listeria monocytogenes and Mycobacterium tuberculosis(162-164). AIM2 also contributes to inflammation in response to bacterial infection in the brain(165). Alternatively, investigation has also shown AIM2 to impede cell survival pathways that promote tumor growth(166- 
168). In the case of colorectal cancer, reduction or lack of expression of AIM 2 is positively correlated with poor outcome(166). Two recent papers indicate that this role of AIM2 is inflammasome-independent and is due to the negative regulation by AIM2 of proliferative signals such as Akt and c-myc signaling $(166,168)$. AIM2 is also protective in the case of breast cancer where it prevents MCF-7 breast cancer cell growth in vitro and tumor growth in vivo(169).

\section{Non-Canonical Inflammasomes}

Aside from the activation of caspase-1 which is referred to as the canonical inflammasome pathway, a non-canonical pathway leading to caspase-11 maturation was first described by Kayagaki et al. who showed that this process is dependent on NLRP3 and ASC(170). Later, caspase-11 was shown to be activated by cytosolic LPS derived from Gram negative bacteria that reside in the cytosol, thereby engaging in the protection of mice against infection by other LPS producing bacteria $(171,172)$. Thus, while TLR4 mediates host response to extracellular LPS, the NLRP3-dependent caspase-11 pathway mediates host response to cytosolic LPS. The cytosolic presence of LPS is a crucial step, as Salmonella which reside in a vacuole does not elicit a caspase-11 response. In turn the expression of caspase-11 is activated by STAT1 downstream of type I or type II interferon. Others showed that caspase-11 is an intracellular receptor of LPS(173). However, caspase-11 also binds to endogenous ligand-oxidized phospholipids to elicit inflammasome-dependent activities(174). More recently, a caspase-11 substrate, gasdermin D, was identified by differential genetic screening strategies, to be important as an effector of pyroptosis and NLRP3-dependent inflammasome activation $(175,176)$.

In addition, to the above mentioned non-canonical pathway, an unconventional one step pathway of inflammasome activation exists in human monocytes in response to LPS alone. This pathway requires Syk activity and $\mathrm{Ca}^{2+}$ flux mediated by internalization of the CD14/ TLR 4 complex. Moreover, caspase- 4 and caspase- 5 have been shown to mediate IL-1a and IL-1 $\beta$ release from human monocytes after LPS stimulation(177).

\section{Inflammasome NLRs in Cancers}

In addition to the disease associations described above, the association of chronic inflammation with cancer is well established with chronic inflammation contributing to a tumor-promoting microenvironment. The following is not intended to be an exhaustive review of the field, but rather is presented to highlight the studies of NLRs and their roles in cancer. For example, the NLRP3 inflammasome remains the most investigated inflammasome with regard to cancer. Several groups have demonstrated the susceptibility of NIrp3 and Casp1 deficient mice to dextran sulfate sodium (DSS)-induced colitis in a model of human ulcerative colitis. Defective inflammasome activation leads to loss of epithelial integrity, enhances leukocyte infiltration and increases chemokine expression in NIrp3 $3^{-/-}$ and Casp $^{-/}$mice, leading to increased mortality(178). These results were supported by Zaki et al., who showed NLRP3 inflammasome functions as a negative regulator of tumorigenesis during colitis-associated cancer, with NLRP3 inflammasome-dependent IL-18 production protecting against colorectal tumorigenesis(179). Another group showed that the 
suppressive impact of NLRP3 on colorectal cancer could be attributed to its enhancement of IL-18 which then activates natural killer cells(180). However, the protective or aggravating function of NLRP3 may be dependent on the severity of disease or factors in the local environment. The (181)NLRP3 inflammasome also appears to play a central role in the pathology of melanomas, gastric cancer and hepatocellular carcinoma(181). The NLRP3 inflammasome is constitutively expressed in human melanoma cells $(182,183)$. In the case of gastric cancer, Mycoplasma hyorhinis was shown to promote tumor development via NLRP3 inflammasome activation(184). Interestingly, IL-1 $\beta$, but not IL-18, released from macrophages treated with $M$. hyorhinis promotes cell migration and invasion to exacerbate gastric cancer. The expression of NLRP3 inflammasome is down-regulated in hepatic parenchymal cells in hepatocellular carcinoma(185). Loss of NLRP3 inflammasome activation positively correlates with a higher pathological grade in hepatocellular carcinogenesis.

NLRP3 inflammasome activation has also been implicated in adaptive immune responses to cancer vaccines(186). The NLRP3 inflammasome is activated during chemotherapy. Dying tumor cells release ATP that is sensed by the $\mathrm{P} 2 \mathrm{X}_{7}$ receptors of dendritic cells leading to NLRP3 inflammasome activation. However when anti-tumor responses elicited by dendritic cell vaccination was tested, NLRP3 expression was found to be upregulated in tumorassociated myeloid derived suppressor cells (MDSCs), thus suppressing anti-tumor response(187). Nlrp ${ }^{-/-}$mice have fewer MDSCs accumulating at the tumor site and increased survival upon dendritic cell vaccination. Since this research focused on different adaptive immune cell populations, the differences may be attributable to differences in tumor cell types, in vaccine formulation or in stimuli for NLRP3 inflammasome activation. Increased IL- $1 \beta$ secretion in the tumor microenvironment has also been linked to promotion of inflammation, early angiogenic response, as well as tumor induction and progression(188, 189).

Additional evidence has linked other inflammasomes to cancer. For instance, $\mathrm{Hu}$ et al. showed that regulation of inflammation-induced tumorigenesis is mediated by NLRC4 and caspase-1(190). In the AOM-DSS inflammation-induced colorectal cancer model, Casp1 $1^{-/}$ and $\mathrm{NIrC4}^{-/}$mice exhibited increased tumor load and number per mice. Caspase-1 and NLRC4 are relatively highly expressed in both colonic epithelial cells and CD45 hematopoietic cells in the colon. In contrast, NLRP3 expression is primarily restricted to the hematopoietic compartment. These results concluded that an intrinsic epithelial cell effect exacerbates tumorigenesis in the absence of caspase-1 or NLRC4 activity.

Multiple associations of NAIP with cancers have been noted. NAIP expression is significantly elevated in malignantly transformed oral squamous cell carcinomas(191). The Naip allele is methylated in normal oral mucosa tissues. NAIP expression is increased in breast cancer(192) and is associated with an unfavorable prognosis. In the case of prostate cancer, several inhibitor of apoptosis protein members including NAIP are increased(193).

Linkage of NLRP6 to cancer has been derived from the study of mouse models of colon cancer. For example, Chen et al. established an association of NLRP6 with a colon cancer model, when they showed that NIrp6 deficient mice are more susceptible to DSS-induced 
colitis and colitis-associated colon tumorigenesis as compared to wild type controls(125). NLRP6 controls epithelial self-renewal and colorectal carcinogenesis upon injury due to DSS.

Lastly, studies of the adaptor ASC have demonstrated a role in various types of cancers. ASC is overexpressed in several tumors, triggering apoptosis and formation of ASC specks. Studies have shown methylation-associated silencing of ASC across many cancer types(194). However, the mechanisms underlying regulation of ASC silencing or overexpression remain largely undetermined. ASC is inactivated in almost $40 \%$ of breast cancers(195). Yokoyama et al. supported these findings by showing ASC methylation present in colorectal cancer tissues(196). Histone deacetylation of the ASC gene is also seen in ovarian cancer. Additionally, aberrant methylation and inactivation of ASC has been seen in glioblastoma, prostate cancer, lung cancer, hepatocellular carcinoma and melanoma(197199). Liu et al. identified a dual role of ASC in human melanoma tumorigenesis with ASC expression in metastatic melanoma down-regulated as compared to levels in primary melanoma(200). This reveals a complex role played by ASC in regulating cell proliferation. ASC may act as a potential modulator of inflammatory responses by coordinating the activity of NLRs and cytokine activating caspases in mammalian cells.

\section{Inflammasome NLRs in Other Diseases}

Above, we discussed the genetic and expression correlations of specific inflammasome genes to various diseases. Here, we intend to highlight where the inflammasome is implicated in other autoimmune and inflammatory diseases. In the case of Alzheimer's disease, caspase-1 expression was elevated in brain samples from Alzheimer's patients as well as from mice carrying mutations associated with familial Alzheimer's disease. Interestingly, mice lacking NIrp3 or Casp1 showed less inflammasome activation and more protection from poor clinical outcomes associated with neuroinflammatory disease(201). It was found that phagocytosis of the $\beta$-amyloid protein by human microglia can activate the NLRP3 inflammasome and cause IL-1 $\beta$ release(53). This NLRP3 activation appears to be stimulated with lysosomal destabilization and subsequent release of cathepsin B caused by $\beta$-amyloid phagocytosis. The NLRP3 inflammasome also plays a significant role in the autoimmune demyelinating disease model of multiple sclerosis (MS) where experimental $\mathrm{Nlrp3}^{-/-}$, Casp $1^{-/}$and $I 118^{-/-}$mice displayed delayed demyelination(202, 203). Moreover, the efficacy of IFN- $\beta$ in an EAE model of MS was dependent on NLRP3 activity(204). Lastly, observations point to a link between inflammasome and the autoimmune disease systemic lupus erythematosus (SLE). Leukocytes from SLE patients have increased AIM2 expression, even though there is no direct correlation between AIM2 expression and SLE disease activity(205). Similarly, in a mouse model of lupus, both IL-1 $\beta$ and IL-18 are important for disease progression, suggesting a possible inflammasome link(206).

\section{Conclusions}

The inflammasome has been a robust field of intensive investigation, uncovering significant revelations of an important family of regulators of health and disease. However, multiple questions remain unaddressed: the identity of ligands for several NLRs, the mechanism(s) of 
ligand binding, the specific signaling pathways for regulation, cell-specific regulation of function in normal as well as in diseased hosts. Moreover, functions of NLRs beyond their roles in immunity remain largely unexplored. Discoveries emerging from investigating NLR biology promise to provide key insights into key pathways regulating immunity, inflammation and homeostasis.

\section{Acknowledgments}

We gratefully acknowledge the support of National Institutes of Health funding (U19-AI109965and U19AI067798) to JPYT and WJB.

\section{References}

1. Harton JA, Linhoff MW, Zhang J, Ting JP. Cutting edge: CATERPILLER: a large family of mammalian genes containing CARD, pyrin, nucleotide-binding, and leucine-rich repeat domains. Journal of immunology (Baltimore, Md: 1950). 2002; 169:4088-4093.

2. Inohara N, Nunez G. NODs: intracellular proteins involved in inflammation and apoptosis. Nat Rev Immunol. 2003; 3:371-382. [PubMed: 12766759]

3. Tschopp J, Martinon F, Burns K. NALPs: a novel protein family involved in inflammation. Nat Rev Mol Cell Biol. 2003; 4:95-104. [PubMed: 12563287]

4. Davis BK, Wen H, Ting JP. The Inflammasome NLRs in Immunity, Inflammation, and Associated Diseases. Annu Rev Immunol. 2010; doi: 10.1146/annurev-immunol-031210-101405

5. Ting JP, Davis BK. CATERPILLER: a novel gene family important in immunity, cell death, and diseases. Annu Rev Immunol. 2005; 23:387-414. [PubMed: 15771576]

6. Ausubel FM. Are innate immune signaling pathways in plants and animals conserved? Nat Immunol. 2005; 6:973-979. [PubMed: 16177805]

7. Davis BK, Roberts RA, Huang MT, Willingham SB, Conti BJ, Brickey WJ, Barker BR, Kwan M, Taxman DJ, Accavitti-Loper MA, Duncan JA, Ting JP. Cutting edge: NLRC5-dependent activation of the inflammasome. J Immunol. 2011; 186:1333-1337. [PubMed: 21191067]

8. Kummer JA, Broekhuizen R, Everett H, Agostini L, Kuijk L, Martinon F, van Bruggen R, Tschopp J. Inflammasome components NALP 1 and 3 show distinct but separate expression profiles in human tissues suggesting a site-specific role in the inflammatory response. J Histochem Cytochem. 2007; 55:443-452. [PubMed: 17164409]

9. Allen IC. Non-Inflammasome Forming NLRs in Inflammation and Tumorigenesis. Front Immunol. 2014:5. [PubMed: 24478774]

10. Claes AK, Zhou JY, Philpott DJ. NOD-Like Receptors: Guardians of Intestinal Mucosal Barriers. Physiology (Bethesda). 2015; 30:241-250. [PubMed: 25933824]

11. Clay GM, Sutterwala FS, Wilson ME. NLR proteins and parasitic disease. Immunol Res. 2014; 59:142-152. [PubMed: 24989828]

12. Hlaing T, Guo RF, Dilley KA, Loussia JM, Morrish TA, Shi MM, Vincenz C, Ward PA. Molecular cloning and characterization of DEFCAP-L and -S, two isoforms of a novel member of the mammalian Ced-4 family of apoptosis proteins. J Biol Chem. 2001; 276:9230-9238. [PubMed: 11076957]

13. Chu ZL, Pio F, Xie Z, Welsh K, Krajewska M, Krajewski S, Godzik A, Reed JC. A novel enhancer of the Apaf1 apoptosome involved in cytochrome c-dependent caspase activation and apoptosis. $\mathrm{J}$ Biol Chem. 2001; 276:9239-9245. [PubMed: 11113115]

14. Yuan JY, Horvitz HR. The Caenorhabditis elegans genes ced-3 and ced-4 act cell autonomously to cause programmed cell death. Dev Biol. 1990; 138:33-41. [PubMed: 2307287]

15. Martinon F, Burns K, Tschopp J. The inflammasome: a molecular platform triggering activation of inflammatory caspases and processing of proIL-beta. Mol Cell. 2002; 10:417-426. [PubMed: 12191486] 
16. Faustin B, Lartigue L, Bruey JM, Luciano F, Sergienko E, Bailly-Maitre B, Volkmann N, Hanein D, Rouiller I, Reed JC. Reconstituted NALP1 inflammasome reveals two-step mechanism of caspase-1 activation. Mol Cell. 2007; 25:713-724. [PubMed: 17349957]

17. Ting JP, Lovering RC, Alnemri ES, Bertin J, Boss JM, Davis BK, Flavell RA, Girardin SE, Godzik A, Harton JA, Hoffman HM, Hugot JP, Inohara N, Mackenzie A, Maltais LJ, Nunez G, Ogura Y, Otten LA, Philpott D, Reed JC, Reith W, Schreiber S, Steimle V, Ward PA. The NLR gene family: a standard nomenclature. Immunity. 2008; 28:285-287. [PubMed: 18341998]

18. Sastalla I, Crown D, Masters SL, McKenzie A, Leppla SH, Moayeri M. Transcriptional analysis of the three Nlrp1 paralogs in mice. BMC Genomics. 2013; 14:188. [PubMed: 23506131]

19. Dwivedi M, Laddha NC, Mansuri MS, Marfatia YS, Begum R. Association of NLRP1 genetic variants and mRNA overexpression with generalized vitiligo and disease activity in a Gujarat population. Br J Dermatol. 2013; 169:1114-1125. [PubMed: 23773036]

20. Jin Y, Mailloux CM, Gowan K, Riccardi SL, LaBerge G, Bennett DC, Fain PR, Spritz RA. NALP1 in vitiligo-associated multiple autoimmune disease. N Engl J Med. 2007; 356:1216-1225. [PubMed: 17377159]

21. Levandowski CB, Mailloux CM, Ferrara TM, Gowan K, Ben S, Jin Y, McFann KK, Holland PJ, Fain PR, Dinarello CA, Spritz RA. NLRP1 haplotypes associated with vitiligo and autoimmunity increase interleukin-1beta processing via the NLRP1 inflammasome. Proc Natl Acad Sci U S A. 2013; 110:2952-2956. [PubMed: 23382179]

22. Magitta NF, Boe Wolff AS, Johansson S, Skinningsrud B, Lie BA, Myhr KM, Undlien DE, Joner G, Njolstad PR, Kvien TK, Forre O, Knappskog PM, Husebye ES. A coding polymorphism in NALP1 confers risk for autoimmune Addison's disease and type 1 diabetes. Genes Immun. 2009; 10:120-124. [PubMed: 18946481]

23. Newman ZL, Printz MP, Liu S, Crown D, Breen L, Miller-Randolph S, Flodman P, Leppla SH, Moayeri M. Susceptibility to anthrax lethal toxin-induced rat death is controlled by a single chromosome 10 locus that includes rNlrp1. PLoS Pathog. 2010; 6:e1000906. [PubMed: 20502689]

24. Terra JK, Cote CK, France B, Jenkins AL, Bozue JA, Welkos SL, LeVine SM, Bradley KA. Resistance to Bacillus anthracis Infection Mediated by a Lethal Toxin Sensitive Allele of Nalp1b/ Nlrp1b1. J Immunol. 2010; 184:17-20. [PubMed: 19949100]

25. Hsu LC, Ali SR, McGillivray S, Tseng PH, Mariathasan S, Humke EW, Eckmann L, Powell JJ, Nizet V, Dixit VM, Karin M. A NOD2-NALP1 complex mediates caspase-1-dependent IL-1beta secretion in response to Bacillus anthracis infection and muramyl dipeptide. Proc Natl Acad Sci U S A. 2008; 105:7803-7808. [PubMed: 18511561]

26. Chavarria-Smith J, Vance RE. Direct proteolytic cleavage of NLRP1B is necessary and sufficient for inflammasome activation by anthrax lethal factor. PLoS Pathog. 2013; 9:e1003452. [PubMed: 23818853]

27. Levinsohn JL, Newman ZL, Hellmich KA, Fattah R, Getz MA, Liu S, Sastalla I, Leppla SH, Moayeri M. Anthrax lethal factor cleavage of nlrp1 is required for activation of the inflammasome. PLoS Pathog. 2012; 8:e1002638. [PubMed: 22479187]

28. Hellmich KA, Levinsohn JL, Fattah R, Newman ZL, Maier N, Sastalla I, Liu S, Leppla SH, Moayeri M. Anthrax lethal factor cleaves mouse nlrp1b in both toxin-sensitive and toxin-resistant macrophages. PLoS One. 2012; 7:e49741. [PubMed: 23152930]

29. Kovarova M, Hesker PR, Jania L, Nguyen M, Snouwaert JN, Xiang Z, Lommatzsch SE, Huang MT, Ting JP, Koller BH. NLRP1-dependent pyroptosis leads to acute lung injury and morbidity in mice. J Immunol. 2012; 189:2006-2016. [PubMed: 22753929]

30. Reubold TF, Hahne G, Wohlgemuth S, Eschenburg S. Crystal structure of the leucine-rich repeat domain of the NOD-like receptor NLRP1: implications for binding of muramyl dipeptide. FEBS Lett. 2014; 588:3327-3332. [PubMed: 25064844]

31. Witola WH, Mui E, Hargrave A, Liu S, Hypolite M, Montpetit A, Cavailles P, Bisanz C, CesbronDelauw MF, Fournie GJ, McLeod R. NALP1 influences susceptibility to human congenital toxoplasmosis, proinflammatory cytokine response, and fate of Toxoplasma gondii-infected monocytic cells. Infect Immun. 2011; 79:756-766. [PubMed: 21098108]

32. Ewald SE, Chavarria-Smith J, Boothroyd JC. NLRP1 is an inflammasome sensor for Toxoplasma gondii. Infect Immun. 2014; 82:460-468. [PubMed: 24218483] 
33. Gorfu G, Cirelli KM, Melo MB, Mayer-Barber K, Crown D, Koller BH, Masters S, Sher A, Leppla SH, Moayeri M, Saeij JP, Grigg ME. Dual role for inflammasome sensors NLRP1 and NLRP3 in murine resistance to Toxoplasma gondii. MBio. 2014:5.

34. Masters SL, Gerlic M, Metcalf D, Preston S, Pellegrini M, O’Donnell JA, McArthur K, Baldwin TM, Chevrier S, Nowell CJ, Cengia LH, Henley KJ, Collinge JE, Kastner DL, Feigenbaum L, Hilton DJ, Alexander WS, Kile BT, Croker BA. NLRP1 inflammasome activation induces pyroptosis of hematopoietic progenitor cells. Immunity. 2012; 37:1009-1023. [PubMed: 23219391]

35. Chi W, Li F, Chen H, Wang Y, Zhu Y, Yang X, Zhu J, Wu F, Ouyang H, Ge J, Weinreb RN, Zhang K, Zhuo Y. Caspase-8 promotes NLRP1/NLRP3 inflammasome activation and IL-1beta production in acute glaucoma. Proc Natl Acad Sci U S A. 2014; 111:11181-11186. [PubMed: 25024200]

36. de Rivero Vaccari JP, Lotocki G, Alonso OF, Bramlett HM, Dietrich WD, Keane RW. Therapeutic neutralization of the NLRP1 inflammasome reduces the innate immune response and improves histopathology after traumatic brain injury. J Cereb Blood Flow Metab. 2009; 29:1251-1261. [PubMed: 19401709]

37. Williams TM, Leeth RA, Rothschild DE, Coutermarsh-Ott SL, McDaniel DK, Simmons AE, Heid B, Cecere TE, Allen IC. The NLRP1 inflammasome attenuates colitis and colitis-associated tumorigenesis. J Immunol. 2015; 194:3369-3380. [PubMed: 25725098]

38. Murphy AJ, Kraakman MJ, Kammoun HL, Dragoljevic D, Lee MK, Lawlor KE, Wentworth JM, Vasanthakumar A, Gerlic M, Whitehead LW, DiRago L, Cengia L, Lane RM, Metcalf D, Vince JE, Harrison LC, Kallies A, Kile BT, Croker BA, Febbraio MA, Masters SL. IL-18 Production from the NLRP1 Inflammasome Prevents Obesity and Metabolic Syndrome. Cell Metab. 2016; 23:155164. [PubMed: 26603191]

39. de Rivero Vaccari JP, Lotocki G, Marcillo AE, Dietrich WD, Keane RW. A molecular platform in neurons regulates inflammation after spinal cord injury. J Neurosci. 2008; 28:3404-3414. [PubMed: 18367607]

40. de Rivero Vaccari JP, Lotocki G, Alonso OF, Bramlett HM, Dietrich WD, Keane RW. Therapeutic neutralization of the NLRP1 inflammasome reduces the innate immune response and improves histopathology after traumatic brain injury. J Cereb Blood Flow Metab. 2009

41. Franklin BS, Bossaller L, De Nardo D, Ratter JM, Stutz A, Engels G, Brenker C, Nordhoff M, Mirandola SR, Al-Amoudi A, Mangan M, Zimmer S, Monks B, Fricke M, Schmidt RE, Espevik T, Jones B, Jarnicki AG, Hansbro PM, Busto P, Marshak-Rothstein A, Hornemann S, Aguzzi A, Kastenmüller W, Latz E. ASC has extracellular and prionoid activities that propagate inflammation. Nat Immunol. 2014; 15:727-737. [PubMed: 24952505]

42. Hoffman HM, Mueller JL, Broide DH, Wanderer AA, Kolodner RD. Mutation of a new gene encoding a putative pyrin-like protein causes familial cold autoinflammatory syndrome and Muckle-Wells syndrome. Nat Genet. 2001; 29:301-305. [PubMed: 11687797]

43. Aksentijevich I, Nowak M, Mallah M, Chae JJ, Watford WT, Hofmann SR, Stein L, Russo R, Goldsmith D, Dent P, Rosenberg HF, Austin F, Remmers EF, Balow JE Jr, Rosenzweig S, Komarow H, Shoham NG, Wood G, Jones J, Mangra N, Carrero H, Adams BS, Moore TL, Schikler K, Hoffman H, Lovell DJ, Lipnick R, Barron K, O'Shea JJ, Kastner DL, GoldbachMansky R. De novo CIAS1 mutations, cytokine activation, and evidence for genetic heterogeneity in patients with neonatal-onset multisystem inflammatory disease (NOMID): a new member of the expanding family of pyrin-associated autoinflammatory diseases. Arthritis Rheum. 2002; 46:33403348. [PubMed: 12483741]

44. Aganna E, Martinon F, Hawkins PN, Ross JB, Swan DC, Booth DR, Lachmann HJ, Bybee A, Gaudet R, Woo P, Feighery C, Cotter FE, Thome M, Hitman GA, Tschopp J, McDermott MF. Association of mutations in the NALP3/CIAS1/PYPAF1 gene with a broad phenotype including recurrent fever, cold sensitivity, sensorineural deafness, and AA amyloidosis. Arthritis Rheum. 2002; 46:2445-2452. [PubMed: 12355493]

45. Feldmann J, Prieur AM, Quartier P, Berquin P, Certain S, Cortis E, Teillac-Hamel D, Fischer A, de Saint Basile G. Chronic infantile neurological cutaneous and articular syndrome is caused by mutations in CIAS1, a gene highly expressed in polymorphonuclear cells and chondrocytes. Am J Hum Genet. 2002; 71:198-203. [PubMed: 12032915] 
46. Manji GA, Wang L, Geddes BJ, Brown M, Merriam S, Al-Garawi A, Mak S, Lora JM, Briskin M, Jurman M, Cao J, DiStefano PS, Bertin J. PYPAF1, a PYRIN-containing Apaf1-like protein that assembles with ASC and regulates activation of NF-kappa B. J Biol Chem. 2002; 277:1157011575. [PubMed: 11786556]

47. Guarda G, Zenger M, Yazdi AS, Schroder K, Ferrero I, Menu P, Tardivel A, Mattmann C, Tschopp J. Differential expression of NLRP3 among hematopoietic cells. J Immunol. 2011; 186:2529_ 2534. [PubMed: 21257968]

48. Kanneganti TD, Body-Malapel M, Amer A, Park JH, Whitfield J, Franchi L, Taraporewala ZF, Miller D, Patton JT, Inohara N, Nunez G. Critical role for Cryopyrin/Nalp3 in activation of caspase-1 in response to viral infection and double-stranded RNA. J Biol Chem. 2006; 281:3656036568. [PubMed: 17008311]

49. Kanneganti TD, Ozoren N, Body-Malapel M, Amer A, Park JH, Franchi L, Whitfield J, Barchet W, Colonna M, Vandenabeele P, Bertin J, Coyle A, Grant EP, Akira S, Nunez G. Bacterial RNA and small antiviral compounds activate caspase-1 through cryopyrin/Nalp3. Nature. 2006; 440:233236. [PubMed: 16407888]

50. Mariathasan S, Weiss DS, Newton K, McBride J, O’Rourke K, Roose-Girma M, Lee WP, Weinrauch Y, Monack DM, Dixit VM. Cryopyrin activates the inflammasome in response to toxins and ATP. Nature. 2006; 440:228-232. [PubMed: 16407890]

51. Martinon F, Petrilli V, Mayor A, Tardivel A, Tschopp J. Gout-associated uric acid crystals activate the NALP3 inflammasome. Nature. 2006; 440:237-241. [PubMed: 16407889]

52. Shi Y, Evans JE, Rock KL. Molecular identification of a danger signal that alerts the immune system to dying cells. Nature. 2003; 425:516-521. [PubMed: 14520412]

53. Halle A, Hornung V, Petzold GC, Stewart CR, Monks BG, Reinheckel T, Fitzgerald KA, Latz E, Moore KJ, Golenbock DT. The NALP3 inflammasome is involved in the innate immune response to amyloid-beta. Nat Immunol. 2008; 9:857-865. [PubMed: 18604209]

54. Scheibner KA, Lutz MA, Boodoo S, Fenton MJ, Powell JD, Horton MR. Hyaluronan fragments act as an endogenous danger signal by engaging TLR2. J Immunol. 2006; 177:1272-1281. [PubMed: 16818787]

55. Cassel SL, Eisenbarth SC, Iyer SS, Sadler JJ, Colegio OR, Tephly LA, Carter AB, Rothman PB, Flavell RA, Sutterwala FS. The Nalp3 inflammasome is essential for the development of silicosis. Proc Natl Acad Sci U S A. 2008; 105:9035-9040. [PubMed: 18577586]

56. Dostert C, Petrilli V, Van Bruggen R, Steele C, Mossman BT, Tschopp J. Innate immune activation through Nalp3 inflammasome sensing of asbestos and silica. Science. 2008; 320:674-677. [PubMed: 18403674]

57. Hornung V, Bauernfeind F, Halle A, Samstad EO, Kono H, Rock KL, Fitzgerald KA, Latz E. Silica crystals and aluminum salts activate the NALP3 inflammasome through phagosomal destabilization. Nat Immunol. 2008; 9:847-856. [PubMed: 18604214]

58. Duewell P, Kono H, Rayner KJ, Sirois CM, Vladimer G, Bauernfeind FG, Abela GS, Franchi L, Nunez G, Schnurr M, Espevik T, Lien E, Fitzgerald KA, Rock KL, Moore KJ, Wright SD, Hornung V, Latz E. NLRP3 inflammasomes are required for atherogenesis and activated by cholesterol crystals. Nature. 2010; 464:1357-1361. [PubMed: 20428172]

59. Rajamaki K, Lappalainen J, Oorni K, Valimaki E, Matikainen S, Kovanen PT, Eklund KK. Cholesterol crystals activate the NLRP3 inflammasome in human macrophages: a novel link between cholesterol metabolism and inflammation. PLoS One. 2010; 5:e11765. [PubMed: 20668705]

60. Li H, Willingham SB, Ting JP, Re F. Cutting edge: inflammasome activation by alum and alum's adjuvant effect are mediated by NLRP3. J Immunol. 2008; 181:17-21. [PubMed: 18566365]

61. Masters SL, Dunne A, Subramanian SL, Hull RL, Tannahill GM, Sharp FA, Becker C, Franchi L, Yoshihara E, Chen Z, Mullooly N, Mielke LA, Harris J, Coll RC, Mills KH, Mok KH, Newsholme P, Nunez G, Yodoi J, Kahn SE, Lavelle EC, O’Neill LA. Activation of the NLRP3 inflammasome by islet amyloid polypeptide provides a mechanism for enhanced IL-1beta in type 2 diabetes. Nat Immunol. 2010; 11:897-904. [PubMed: 20835230] 
62. Vandanmagsar B, Youm YH, Ravussin A, Galgani JE, Stadler K, Mynatt RL, Ravussin E, Stephens JM, Dixit VD. The NLRP3 inflammasome instigates obesity-induced inflammation and insulin resistance. Nat Med. 2011; 17:179-188. [PubMed: 21217695]

63. Wen H, Gris D, Lei Y, Jha S, Zhang L, Huang MT, Brickey WJ, Ting JP. Fatty acid-induced NLRP3-ASC inflammasome activation interferes with insulin signaling. Nat Immunol. 2011; 12:408-415. [PubMed: 21478880]

64. Shio MT, Eisenbarth SC, Savaria M, Vinet AF, Bellemare MJ, Harder KW, Sutterwala FS, Bohle DS, Descoteaux A, Flavell RA, Olivier M. Malarial hemozoin activates the NLRP3 inflammasome through Lyn and Syk kinases. PLoS Pathog. 2009; 5:e1000559. [PubMed: 19696895]

65. Abdul-Sater AA, Tattoli I, Jin L, Grajkowski A, Levi A, Koller BH, Allen IC, Beaucage SL, Fitzgerald KA, Ting JP, Cambier JC, Girardin SE, Schindler C. Cyclic-di-GMP and cyclic-di-AMP activate the NLRP3 inflammasome. EMBO Rep. 2013; 14:900-906. [PubMed: 24008845]

66. Bauernfeind FG, Horvath G, Stutz A, Alnemri ES, MacDonald K, Speert D, Fernandes-Alnemri T, Wu J, Monks BG, Fitzgerald KA, Hornung V, Latz E. Cutting edge: NF-kappaB activating pattern recognition and cytokine receptors license NLRP3 inflammasome activation by regulating NLRP3 expression. J Immunol. 2009; 183:787-791. [PubMed: 19570822]

67. Sutterwala FS, Ogura Y, Szczepanik M, Lara-Tejero M, Lichtenberger GS, Grant EP, Bertin J, Coyle AJ, Galan JE, Askenase PW, Flavell RA. Critical role for NALP3/CIAS1/Cryopyrin in innate and adaptive immunity through its regulation of caspase-1. Immunity. 2006; 24:317-327. [PubMed: 16546100]

68. Mariathasan S, Newton K, Monack DM, Vucic D, French DM, Lee WP, Roose-Girma M, Erickson $\mathrm{S}$, Dixit VM. Differential activation of the inflammasome by caspase-1 adaptors ASC and Ipaf. Nature. 2004; 430:213-218. [PubMed: 15190255]

69. Shao W, Yeretssian G, Doiron K, Hussain SN, Saleh M. The caspase-1 digestome identifies the glycolysis pathway as a target during infection and septic shock. The Journal of biological chemistry. 2007; 282:36321-36329. [PubMed: 17959595]

70. Keller M, Ruegg A, Werner S, Beer HD. Active caspase-1 is a regulator of unconventional protein secretion. Cell. 2008; 132:818-831. [PubMed: 18329368]

71. Li P, Allen H, Banerjee S, Seshadri T. Characterization of mice deficient in interleukin-1 beta converting enzyme. Journal of cellular biochemistry. 1997; 64:27-32. [PubMed: 9015751]

72. Compan V, Baroja-Mazo A, Lopez-Castejon G, Gomez AI, Martinez CM, Angosto D, Montero MT, Herranz AS, Bazan E, Reimers D, Mulero V, Pelegrin P. Cell volume regulation modulates NLRP3 inflammasome activation. Immunity. 2012; 37:487-500. [PubMed: 22981536]

73. Lee GS, Subramanian N, Kim AI, Aksentijevich I, Goldbach-Mansky R, Sacks DB, Germain RN, Kastner DL, Chae JJ. The calcium-sensing receptor regulates the NLRP3 inflammasome through Ca2+ and cAMP. Nature. 2012; 492:123-127. [PubMed: 23143333]

74. Murakami T, Ockinger J, Yu J, Byles V, McColl A, Hofer AM, Horng T. Critical role for calcium mobilization in activation of the NLRP3 inflammasome. Proc Natl Acad Sci U S A. 2012; 109:11282-11287. [PubMed: 22733741]

75. Zhong Z, Zhai Y, Liang S, Mori Y, Han R, Sutterwala FS, Qiao L. TRPM2 links oxidative stress to NLRP3 inflammasome activation. Nat Commun. 2013; 4:1611. [PubMed: 23511475]

76. Schorn C, Frey B, Lauber K, Janko C, Strysio M, Keppeler H, Gaipl US, Voll RE, Springer E, Munoz LE, Schett G, Herrmann M. Sodium overload and water influx activate the NALP3 inflammasome. J Biol Chem. 2011; 286:35-41. [PubMed: 21051542]

77. Cruz CM, Rinna A, Forman HJ, Ventura AL, Persechini PM, Ojcius DM. ATP activates a reactive oxygen species-dependent oxidative stress response and secretion of proinflammatory cytokines in macrophages. J Biol Chem. 2007; 282:2871-2879. [PubMed: 17132626]

78. Shimada K, Crother TR, Karlin J, Dagvadorj J, Chiba N, Chen S, Ramanujan VK, Wolf AJ, Vergnes L, Ojcius DM, Rentsendorj A, Vargas M, Guerrero C, Wang Y, Fitzgerald KA, Underhill DM, Town T, Arditi M. Oxidized mitochondrial DNA activates the NLRP3 inflammasome during apoptosis. Immunity. 2012; 36:401-414. [PubMed: 22342844]

79. Nakahira K, Haspel JA, Rathinam VAK, Lee S-J, Dolinay T, Lam HC, Englert JA, Rabinovitch M, Cernadas M, Kim HP, Fitzgerald KA, Ryter SW, Choi AMK. Autophagy proteins regulate innate 
immune responses by inhibiting the release of mitochondrial DNA mediated by the NALP3 inflammasome. Nat Immunol. 2011; 12:222-230. [PubMed: 21151103]

80. Boschan C, Witt O, Lohse P, Foeldvari I, Zappel H, Schweigerer L. Neonatal-onset multisystem inflammatory disease (NOMID) due to a novel S331R mutation of the CIAS1 gene and response to interleukin-1 receptor antagonist treatment. American journal of medical geneticsPart A. 2006; 140:883-886.

81. Kone-Paut I, Sanchez E, Le Quellec A, Manna R, Touitou I. Autoinflammatory gene mutations in Behcet's disease. Annals of the Rheumatic Diseases. 2007

82. McDermott MF, Aksentijevich I. The autoinflammatory syndromes. Curr Opin Allergy Clin Immunol. 2002; 2:511-516. [PubMed: 14752334]

83. Robbins GR, Wen H, Ting JP. Inflammasomes and metabolic disorders: old genes in modern diseases. Mol Cell. 2014; 54:297-308. [PubMed: 24766894]

84. Stojanov S, Kastner DL. Familial autoinflammatory diseases: genetics, pathogenesis and treatment. Curr Opin Rheumatol. 2005; 17:586-599. [PubMed: 16093838]

85. Dode C, Le Du N, Cuisset L, Letourneur F, Berthelot JM, Vaudour G, Meyrier A, Watts RA, Scott DG, Nicholls A, Granel B, Frances C, Garcier F, Edery P, Boulinguez S, Domergues JP, Delpech M, Grateau G. New mutations of CIAS1 that are responsible for Muckle-Wells syndrome and familial cold urticaria: a novel mutation underlies both syndromes. Am J Hum Genet. 2002; 70:1498-1506. [PubMed: 11992256]

86. Hoffman HM, Gregory SG, Mueller JL, Tresierras M, Broide DH, Wanderer AA, Kolodner RD. Fine structure mapping of CIAS1: identification of an ancestral haplotype and a common FCAS mutation, L353P. Hum Genet. 2003; 112:209-216. [PubMed: 12522564]

87. Ting JP, Kastner DL, Hoffman HM. CATERPILLERs, pyrin and hereditary immunological disorders. Nat Rev Immunol. 2006; 6:183-195. [PubMed: 16498449]

88. Dinarello CA, van der Meer JW. Treating inflammation by blocking interleukin-1 in humans. Semin Immunol. 2013; 25:469-484. [PubMed: 24275598]

89. Dinarello CA, Simon A, van der Meer JWM. Treating inflammation by blocking interleukin-1 in a broad spectrum of diseases. Nat Rev Drug Discov. 2012; 11:633-652. [PubMed: 22850787]

90. Goldbach-Mansky R, Dailey NJ, Canna SW, Gelabert A, Jones J, Rubin BI, Kim HJ, Brewer C, Zalewski C, Wiggs E, Hill S, Turner ML, Karp BI, Aksentijevich I, Pucino F, Penzak SR, Haverkamp MH, Stein L, Adams BS, Moore TL, Fuhlbrigge RC, Shaham B, Jarvis JN, O'Neil K, Vehe RK, Beitz LO, Gardner G, Hannan WP, Warren RW, Horn W, Cole JL, Paul SM, Hawkins PN, Pham TH, Snyder C, Wesley RA, Hoffmann SC, Holland SM, Butman JA, Kastner DL. Neonatal-Onset Multisystem Inflammatory Disease Responsive to Interleukin-1 $\beta$ Inhibition. N Engl J Med. 2006; 355:581-592. [PubMed: 16899778]

91. Cai X, Chen J, Xu H, Liu S, Jiang QX, Halfmann R, Chen ZJ. Prion-like polymerization underlies signal transduction in antiviral immune defense and inflammasome activation. Cell. 2014; 156:1207-1222. [PubMed: 24630723]

92. Lu A, Magupalli VG, Ruan J, Yin Q, Atianand MK, Vos MR, Schroder GF, Fitzgerald KA, Wu H, Egelman EH. Unified polymerization mechanism for the assembly of ASC-dependent inflammasomes. Cell. 2014; 156:1193-1206. [PubMed: 24630722]

93. Miao EA, Alpuche-Aranda CM, Dors M, Clark AE, Bader MW, Miller SI, Aderem A. Cytoplasmic flagellin activates caspase-1 and secretion of interleukin 1beta via Ipaf. Nature immunology. 2006; 7:569-575. [PubMed: 16648853]

94. Amer A, Franchi L, Kanneganti TD, Body-Malapel M, Ozoren N, Brady G, Meshinchi S, Jagirdar R, Gewirtz A, Akira S, Nunez G. Regulation of Legionella phagosome maturation and infection through flagellin and host Ipaf. The Journal of biological chemistry. 2006; 281:35217-35223. [PubMed: 16984919]

95. Suzuki T, Franchi L, Toma C, Ashida H, Ogawa M, Yoshikawa Y, Mimuro H, Inohara N, Sasakawa C, Nunez G. Differential regulation of caspase-1 activation, pyroptosis, and autophagy via Ipaf and ASC in Shigella-infected macrophages. PLoS Pathog. 2007; 3:e111. [PubMed: 17696608]

96. Hu Z, Yan C, Liu P, Huang Z, Ma R, Zhang C, Wang R, Zhang Y, Martinon F, Miao D, Deng H, Wang J, Chang J, Chai J. Crystal structure of NLRC4 reveals its autoinhibition mechanism. Science. 2013; 341:172-175. [PubMed: 23765277] 
97. Poyet JL, Srinivasula SM, Tnani M, Razmara M, Fernandes-Alnemri T, Alnemri ES. Identification of Ipaf, a human caspase-1-activating protein related to Apaf-1. The Journal of biological chemistry. 2001; 276:28309-28313. [PubMed: 11390368]

98. Geddes BJ, Wang L, Huang WJ, Lavellee M, Manji GA, Brown M, Jurman M, Cao J, Morgenstern J, Merriam S, Glucksmann MA, DiStefano PS, Bertin J. Human CARD12 is a novel CED4/Apaf-1 family member that induces apoptosis. Biochem Biophys Res Commun. 2001; 284:77-82. [PubMed: 11374873]

99. Franchi L, Amer A, Body-Malapel M, Kanneganti TD, Ozoren N, Jagirdar R, Inohara N, Vandenabeele P, Bertin J, Coyle A, Grant EP, Nunez G. Cytosolic flagellin requires Ipaf for activation of caspase-1 and interleukin 1beta in salmonella-infected macrophages. Nature immunology. 2006; 7:576-582. [PubMed: 16648852]

100. Sutterwala FS, Mijares LA, Li L, Ogura Y, Kazmierczak BI, Flavell RA. Immune recognition of Pseudomonas aeruginosa mediated by the IPAF/NLRC4 inflammasome. J Exp Med. 2007; 204:3235-3245. [PubMed: 18070936]

101. Yang J, Zhao Y, Shi J, Shao F. Human NAIP and mouse NAIP1 recognize bacterial type III secretion needle protein for inflammasome activation. Proc Natl Acad Sci U S A. 2013; 110:14408-14413. [PubMed: 23940371]

102. Kofoed EM, Vance RE. Innate immune recognition of bacterial ligands by NAIPs determines inflammasome specificity. Nature. 2011; 477:592-595. [PubMed: 21874021]

103. Zhao Y, Yang J, Shi J, Gong YN, Lu Q, Xu H, Liu L, Shao F. The NLRC4 inflammasome receptors for bacterial flagellin and type III secretion apparatus. Nature. 2011; 477:596-600. [PubMed: 21918512]

104. Rayamajhi M, Zak DE, Chavarria-Smith J, Vance RE, Miao EA. Cutting edge: Mouse NAIP1 detects the type III secretion system needle protein. J Immunol. 2013; 191:3986-3989. [PubMed: 24043898]

105. Zamboni DS, Kobayashi KS, Kohlsdorf T, Ogura Y, Long EM, Vance RE, Kuida K, Mariathasan S, Dixit VM, Flavell RA, Dietrich WF, Roy CR. The Bircle cytosolic pattern-recognition receptor contributes to the detection and control of Legionella pneumophila infection. Nat Immunol. 2006; 7:318-325. [PubMed: 16444259]

106. Lightfield KL, Persson J, Brubaker SW, Witte CE, von Moltke J, Dunipace EA, Henry T, Sun YH, Cado D, Dietrich WF, Monack DM, Tsolis RM, Vance RE. Critical function for Naip5 in inflammasome activation by a conserved carboxy-terminal domain of flagellin. Nat Immunol. 2008; 9:1171-1178. [PubMed: 18724372]

107. Tenthorey JL, Kofoed EM, Daugherty MD, Malik HS, Vance RE. Molecular basis for specific recognition of bacterial ligands by NAIP/NLRC4 inflammasomes. Mol Cell. 2014; 54:17-29. [PubMed: 24657167]

108. Rauch I, Tenthorey JL, Nichols RD, Al Moussawi K, Kang JJ, Kang C, Kazmierczak BI, Vance RE. NAIP proteins are required for cytosolic detection of specific bacterial ligands in vivo. J Exp Med. 2016; 213:657-665. [PubMed: 27045008]

109. Zhao Y, Shi J, Shi X, Wang Y, Wang F, Shao F. Genetic functions of the NAIP family of inflammasome receptors for bacterial ligands in mice. J Exp Med. 2016; 213:647-656. [PubMed: 27114610]

110. Diebolder CA, Halff EF, Koster AJ, Huizinga EG, Koning RI. Cryoelectron Tomography of the NAIP5/NLRC4 Inflammasome: Implications for NLR Activation. Structure. 2015; 23:2349_ 2357. [PubMed: 26585513]

111. Hu Z, Zhou Q, Zhang C, Fan S, Cheng W, Zhao Y, Shao F, Wang HW, Sui SF, Chai J. Structural and biochemical basis for induced self-propagation of NLRC4. Science. 2015; 350:399-404. [PubMed: 26449475]

112. Zhang L, Chen S, Ruan J, Wu J, Tong AB, Yin Q, Li Y, David L, Lu A, Wang WL, Marks C, Ouyang Q, Zhang X, Mao Y, Wu H. Cryo-EM structure of the activated NAIP2-NLRC4 inflammasome reveals nucleated polymerization. Science. 2015; 350:404-409. [PubMed: 26449474]

113. Sellin ME, Muller AA, Felmy B, Dolowschiak T, Diard M, Tardivel A, Maslowski KM, Hardt WD. Epithelium-intrinsic NAIP/NLRC4 inflammasome drives infected enterocyte expulsion to 
restrict Salmonella replication in the intestinal mucosa. Cell Host Microbe. 2014; 16:237-248. [PubMed: 25121751]

114. Maier JK, Lahoua Z, Gendron NH, Fetni R, Johnston A, Davoodi J, Rasper D, Roy S, Slack RS, Nicholson DW, MacKenzie AE. The neuronal apoptosis inhibitory protein is a direct inhibitor of caspases 3 and 7. J Neurosci. 2002; 22:2035-2043. [PubMed: 11896143]

115. Davoodi J, Ghahremani MH, Es-Haghi A, Mohammad-Gholi A, Mackenzie A. Neuronal apoptosis inhibitory protein, NAIP, is an inhibitor of procaspase-9. Int J Biochem Cell Biol. 2010; 42:958-964. [PubMed: 20171302]

116. Vinzing M, Eitel J, Lippmann J, Hocke AC, Zahlten J, Slevogt H, N'Guessan PD, Gunther S, Schmeck B, Hippenstiel S, Flieger A, Suttorp N, Opitz B. NAIP and Ipaf control Legionella pneumophila replication in human cells. J Immunol. 2008; 180:6808-6815. [PubMed: 18453601]

117. Roy N, Mahadevan MS, McLean M, Shutler G, Yaraghi Z, Farahani R, Baird S, Besner-Johnston A, Lefebvre C, Kang X, et al. The gene for neuronal apoptosis inhibitory protein is partially deleted in individuals with spinal muscular atrophy. Cell. 1995; 80:167-178. [PubMed: 7813013]

118. Wirth B, Hahnen E, Morgan K, DiDonato CJ, Dadze A, Rudnik-Schoneborn S, Simard LR, Zerres K, Burghes AH. Allelic association and deletions in autosomal recessive proximal spinal muscular atrophy: association of marker genotype with disease severity and candidate cDNAs. Hum Mol Genet. 1995; 4:1273-1284. [PubMed: 7581364]

119. Theodorou L, Nicolaou P, Koutsou P, Georghiou A, Anastasiadou V, Tanteles G, Kyriakides T, Zamba-Papanicolaou E, Christodoulou K. Genetic findings of Cypriot spinal muscular atrophy patients. Neurol Sci. 2015; 36:1829-1834. [PubMed: 26017350]

120. Canna SW, de Jesus AA, Gouni S, Brooks SR, Marrero B, Liu Y, DiMattia MA, Zaal KJ, Sanchez GA, Kim H, Chapelle D, Plass N, Huang Y, Villarino AV, Biancotto A, Fleisher TA, Duncan JA, O'Shea JJ, Benseler S, Grom A, Deng Z, Laxer RM, Goldbach-Mansky R. An activating NLRC4 inflammasome mutation causes autoinflammation with recurrent macrophage activation syndrome. Nat Genet. 2014; 46:1140-1146. [PubMed: 25217959]

121. Grenier JM, Wang L, Manji GA, Huang WJ, Al-Garawi A, Kelly R, Carlson A, Merriam S, Lora JM, Briskin M, DiStefano PS, Bertin J. Functional screening of five PYPAF family members identifies PYPAF5 as a novel regulator of NF-kappaB and caspase-1. FEBS Lett. 2002; 530:7378. [PubMed: 12387869]

122. Anand PK, Kanneganti TD. Targeting NLRP6 to enhance immunity against bacterial infections. Future Microbiol. 2012; 7:1239-1242. [PubMed: 23075441]

123. Anand PK, Kanneganti TD. NLRP6 in infection and inflammation. Microbes Infect. 2013; 15:661-668. [PubMed: 23811097]

124. Anand PK, Malireddi RK, Lukens JR, Vogel P, Bertin J, Lamkanfi M, Kanneganti TD. NLRP6 negatively regulates innate immunity and host defence against bacterial pathogens. Nature. 2012; 488:389-393. [PubMed: 22763455]

125. Chen GY, Liu M, Wang F, Bertin J, Nunez G. A Functional Role for Nlrp6 in Intestinal Inflammation and Tumorigenesis. J Immunol. 2011; doi: 10.4049/jimmunol.1100412

126. Normand S, Delanoye-Crespin A, Bressenot A, Huot L, Grandjean T, Peyrin-Biroulet L, Lemoine Y, Hot D, Chamaillard M. Nod-like receptor pyrin domain-containing protein 6 (NLRP6) controls epithelial self-renewal and colorectal carcinogenesis upon injury. Proc Natl Acad Sci U S A. 2011; doi: 10.1073/pnas.1100981108

127. Kempster SL, Belteki G, Forhead AJ, Fowden AL, Catalano RD, Lam BY, McFarlane I, Charnock-Jones DS, Smith GC. Developmental control of the Nlrp6 inflammasome and a substrate, IL-18, in mammalian intestine. Am J Physiol Gastrointest Liver Physiol. 2011; 300:G253-263. [PubMed: 21088234]

128. Elinav E, Strowig T, Kau AL, Henao-Mejia J, Thaiss CA, Booth CJ, Peaper DR, Bertin J, Eisenbarth SC, Gordon JI, Flavell RA. NLRP6 inflammasome is a regulator of colonic microbial ecology and risk for colitis. Cell. 2011; 145:745-757. [PubMed: 21565393]

129. Seregin SS, Golovchenko N, Schaf B, Chen J, Eaton KA, Chen GY. NLRP6 function in inflammatory monocytes reduces susceptibility to chemically induced intestinal injury. Mucosal Immunol. 2016; doi: 10.1038/mi.2016.55 
130. Levy M, Thaiss CA, Zeevi D, Dohnalova L, Zilberman-Schapira G, Mahdi JA, David E, Savidor A, Korem T, Herzig Y, Pevsner-Fischer M, Shapiro H, Christ A, Harmelin A, Halpern Z, Latz E, Flavell RA, Amit I, Segal E, Elinav E. Microbiota-Modulated Metabolites Shape the Intestinal Microenvironment by Regulating NLRP6 Inflammasome Signaling. Cell. 2015; 163:1428-1443. [PubMed: 26638072]

131. Wang P, Zhu S, Yang L, Cui S, Pan W, Jackson R, Zheng Y, Rongvaux A, Sun Q, Yang G, Gao S, Lin R, You F, Flavell R, Fikrig E. Nlrp6 regulates intestinal antiviral innate immunity. Science. 2015; 350:826-830. [PubMed: 26494172]

132. Wlodarska M, Thaiss CA, Nowarski R, Henao-Mejia J, Zhang JP, Brown EM, Frankel G, Levy M, Katz MN, Philbrick WM, Elinav E, Finlay BB, Flavell RA. NLRP6 inflammasome orchestrates the colonic host-microbial interface by regulating goblet cell mucus secretion. Cell. 2014; 156:1045-1059. [PubMed: 24581500]

133. Birchenough GM, Nystrom EE, Johansson ME, Hansson GC. A sentinel goblet cell guards the colonic crypt by triggering Nlrp6-dependent Muc2 secretion. Science. 2016; 352:1535-1542. [PubMed: 27339979]

134. Triantafilou K, Kar S, van Kuppeveld FJ, Triantafilou M. Rhinovirus-induced calcium flux triggers NLRP3 and NLRC5 activation in bronchial cells. Am J Respir Cell Mol Biol. 2013; 49:923-934. [PubMed: 23815151]

135. Yao Y, Wang Y, Chen F, Huang Y, Zhu S, Leng Q, Wang H, Shi Y, Qian Y. NLRC5 regulates MHC class I antigen presentation in host defense against intracellular pathogens. Cell Res. 2012; 22:836-847. [PubMed: 22491475]

136. Pinheiro AS, Proell M, Eibl C, Page R, Schwarzenbacher R, Peti W. Three-dimensional Structure of the NLRP7 Pyrin Domain: INSIGHT INTO PYRIN-PYRIN-MEDIATED EFFECTOR DOMAIN SIGNALING IN INNATE IMMUNITY*. J Biol Chem. 2010; 285:27402-27410. [PubMed: 20547486]

137. Khare S, Dorfleutner A, Bryan NB, Yun C, Radian AD, de Almeida L, Rojanasakul Y, Stehlik C. An NLRP7-containing inflammasome mediates recognition of microbial lipopeptides in human macrophages. Immunity. 2012; 36:464-476. [PubMed: 22361007]

138. Radian AD, Khare S, Chu LH, Dorfleutner A, Stehlik C. ATP binding by NLRP7 is required for inflammasome activation in response to bacterial lipopeptides. Mol Immunol. 2015; 67:294-302. [PubMed: 26143398]

139. Slim R, Wallace EP. NLRP7 and the Genetics of Hydatidiform Moles: Recent Advances and New Challenges. Front Immunol. 2013; 4:242. [PubMed: 23970884]

140. Singer H, Biswas A, Nuesgen N, Oldenburg J, El-Maarri O. NLRP7, Involved in Hydatidiform Molar Pregnancy (HYDM1), Interacts with the Transcriptional Repressor ZBTB16. PLoS One. 2015; 10:e0130416. [PubMed: 26121690]

141. Lich JD, Williams KL, Moore CB, Arthur JC, Davis BK, Taxman DJ, Ting JP. Monarch-1 suppresses non-canonical NF-kappaB activation and p52-dependent chemokine expression in monocytes. Journal of immunology (Baltimore, Md: 1950). 2007; 178:1256-1260.

142. Williams KL, Lich JD, Duncan JA, Reed W, Rallabhandi P, Moore C, Kurtz S, Coffield VM, Accavitti-Loper MA, Su L, Vogel SN, Braunstein M, Ting JP. The CATERPILLER protein monarch-1 is an antagonist of toll-like receptor-, tumor necrosis factor alpha-, and Mycobacterium tuberculosis-induced pro-inflammatory signals. The Journal of biological chemistry. 2005; 280:39914-39924. [PubMed: 16203735]

143. Pinheiro AS, Eibl C, Ekman-Vural Z, Schwarzenbacher R, Peti W. The NLRP12 pyrin domain: structure, dynamics, and functional insights. J Mol Biol. 2011; 413:790-803. [PubMed: 21978668]

144. Williams KL, Taxman DJ, Linhoff MW, Reed W, Ting JP. Cutting edge: Monarch-1: a pyrin/ nucleotide-binding domain/leucine-rich repeat protein that controls classical and nonclassical MHC class I genes. Journal of immunology (Baltimore, Md: 1950). 2003; 170:5354-5358.

145. Wang L, Manji GA, Grenier JM, Al-Garawi A, Merriam S, Lora JM, Geddes BJ, Briskin M, DiStefano PS, Bertin J. PYPAF7, a novel PYRIN-containing Apaf1-like protein that regulates activation of NF-kappa B and caspase-1-dependent cytokine processing. J Biol Chem. 2002; 277:29874-29880. [PubMed: 12019269] 
146. Ataide MA, Andrade WA, Zamboni DS, Wang D, do Souza MC, Franklin BS, Elian S, Martins FS, Pereira D, Reed G, Fitzgerald KA, Golenbock DT, Gazzinelli RT. Malaria-induced NLRP12/ NLRP3-dependent caspase-1 activation mediates inflammation and hypersensitivity to bacterial superinfection. PLoS Pathog. 2014; 10:e1003885. [PubMed: 24453977]

147. Vladimer GI, Weng D, Paquette SW, Vanaja SK, Rathinam VA, Aune MH, Conlon JE, Burbage JJ, Proulx MK, Liu Q, Reed G, Mecsas JC, Iwakura Y, Bertin J, Goguen JD, Fitzgerald KA, Lien E. The NLRP12 Inflammasome Recognizes Yersinia pestis. Immunity. 2012; 37:96-107. [PubMed: 22840842]

148. Zaki MH, Vogel P, Malireddi RK, Body-Malapel M, Anand PK, Bertin J, Green DR, Lamkanfi M, Kanneganti TD. The NOD-like receptor NLRP12 attenuates colon inflammation and tumorigenesis. Cancer Cell. 2011; 20:649-660. [PubMed: 22094258]

149. Allen IC, Wilson JE, Schneider M, Lich JD, Roberts RA, Arthur JC, Woodford RM, Davis BK, Uronis JM, Herfarth HH, Jobin C, Rogers AB, Ting JP. NLRP12 suppresses colon inflammation and tumorigenesis through the negative regulation of noncanonical NF-kappaB signaling. Immunity. 2012; 36:742-754. [PubMed: 22503542]

150. Zaki MH, Man SM, Vogel P, Lamkanfi M, Kanneganti TD. Salmonella exploits NLRP12dependent innate immune signaling to suppress host defenses during infection. Proc Natl Acad Sci U S A. 2014; 111:385-390. [PubMed: 24347638]

151. Allen IC, McElvania-TeKippe E, Wilson JE, Lich JD, Arthur JC, Sullivan JT, Braunstein M, Ting JP. Characterization of NLRP12 during the in vivo host immune response to Klebsiella pneumoniae and Mycobacterium tuberculosis. PLoS One. 2013; 8:e60842. [PubMed: 23577168]

152. Jeru I, Duquesnoy P, Fernandes-Alnemri T, Cochet E, Yu JW, Lackmy-Port-Lis M, Grimprel E, Landman-Parker J, Hentgen V, Marlin S, McElreavey K, Sarkisian T, Grateau G, Alnemri ES, Amselem S. Mutations in NALP12 cause hereditary periodic fever syndromes. Proc Natl Acad Sci U S A. 2008; 105:1614-1619. [PubMed: 18230725]

153. Hornung V, Ablasser A, Charrel-Dennis M, Bauernfeind F, Horvath G, Caffrey DR, Latz E, Fitzgerald KA. AIM2 recognizes cytosolic dsDNA and forms a caspase-1-activating inflammasome with ASC. Nature. 2009; 458:514-518. [PubMed: 19158675]

154. Jones JW, Kayagaki N, Broz P, Henry T, Newton K, O'Rourke K, Chan S, Dong J, Qu Y, RooseGirma M, Dixit VM, Monack DM. Absent in melanoma 2 is required for innate immune recognition of Francisella tularensis. Proc Natl Acad Sci U S A. 2010; 107:9771-9776. [PubMed: 20457908]

155. Sagulenko V, Thygesen SJ, Sester DP, Idris A, Cridland JA, Vajjhala PR, Roberts TL, Schroder K, Vince JE, Hill JM, Silke J, Stacey KJ. AIM2 and NLRP3 inflammasomes activate both apoptotic and pyroptotic death pathways via ASC. Cell Death Differ. 2013; 20:1149-1160. [PubMed: 23645208]

156. Warren SE, Armstrong A, Hamilton MK, Mao DP, Leaf IA, Miao EA, Aderem A. Cutting edge: Cytosolic bacterial DNA activates the inflammasome via Aim2. J Immunol. 2010; 185:818-821. [PubMed: 20562263]

157. DeYoung KL, Ray ME, Su YA, Anzick SL, Johnstone RW, Trapani JA, Meltzer PS, Trent JM. Cloning a novel member of the human interferon-inducible gene family associated with control of tumorigenicity in a model of human melanoma. Oncogene. 1997; 15:453-457. [PubMed: 9242382]

158. Burckstummer T, Baumann C, Bluml S, Dixit E, Durnberger G, Jahn H, Planyavsky M, Bilban M, Colinge J, Bennett KL, Superti-Furga G. An orthogonal proteomic-genomic screen identifies AIM2 as a cytoplasmic DNA sensor for the inflammasome. Nat Immunol. 2009; 10:266-272. [PubMed: 19158679]

159. Fernandes-Alnemri T, Yu JW, Juliana C, Solorzano L, Kang S, Wu J, Datta P, McCormick M, Huang L, McDermott E, Eisenlohr L, Landel CP, Alnemri ES. The AIM2 inflammasome is critical for innate immunity against Francisella tularensis. Nat Immunol. 2010; 11:385-393. [PubMed: 20351693]

160. Jin T, Perry A, Smith P, Jiang J, Xiao TS. Structure of the Absent in Melanoma 2 (AIM2) Pyrin Domain Provides Insights into the Mechanisms of AIM2 Autoinhibition and Inflammasome Assembly*. J Biol Chem. 2013; 288:13225-13235. [PubMed: 23530044] 
161. Wang LJ, Huang HY, Huang MP, Liou W, Chang YT, Wu CC, Ojcius DM, Chang YS. The Microtubule-associated Protein EB1 Links AIM2 Inflammasomes with Autophagy-dependent Secretion*. J Biol Chem. 2014; 289:29322-29333. [PubMed: 25164813]

162. Rathinam VA, Jiang Z, Waggoner SN, Sharma S, Cole LE, Waggoner L, Vanaja SK, Monks BG, Ganesan S, Latz E, Hornung V, Vogel SN, Szomolanyi-Tsuda E, Fitzgerald KA. The AIM2 inflammasome is essential for host-defense against cytosolic bacteria and DNA viruses. Nat Immunol. 2010; 11:395-402. [PubMed: 20351692]

163. Saiga H, Kitada S, Shimada Y, Kamiyama N, Okuyama M, Makino M, Yamamoto M, Takeda K. Critical role of AIM2 in Mycobacterium tuberculosis infection. Int Immunol. 2012; 24:637-644. [PubMed: 22695634]

164. Sauer JD, Witte CE, Zemansky J, Hanson B, Lauer P, Portnoy DA. Listeria monocytogenes that lyse in the macrophage cytosol trigger AIM2-mediated pyroptosis. Cell Host Microbe. 2010; 7:412-419. [PubMed: 20417169]

165. Hanamsagar R, Aldrich A, Kielian T. Critical role for the AIM2 inflammasome during acute central nervous system bacterial infection. J Neurochem. 2014; 129:704-711. [PubMed: 24484406]

166. Man SM, Zhu Q, Zhu L, Liu Z, Karki R, Malik A, Sharma D, Li L, Malireddi RK, Gurung P, Neale G, Olsen SR, Carter RA, McGoldrick DJ, Wu G, Finkelstein D, Vogel P, Gilbertson RJ, Kanneganti TD. Critical Role for the DNA Sensor AIM2 in Stem Cell Proliferation and Cancer. Cell. 2015; 162:45-58. [PubMed: 26095253]

167. Patsos G, Germann A, Gebert J, Dihlmann S. Restoration of absent in melanoma 2 (AIM2) induces G2/M cell cycle arrest and promotes invasion of colorectal cancer cells. Int J Cancer. 2010; 126:1838-1849. [PubMed: 19795419]

168. Wilson JE, Petrucelli AS, Chen L, Koblansky AA, Truax AD, Oyama Y, Rogers AB, Brickey WJ, Wang Y, Schneider M, Muhlbauer M, Chou WC, Barker BR, Jobin C, Allbritton NL, Ramsden DA, Davis BK, Ting JP. Inflammasome-independent role of AIM2 in suppressing colon tumorigenesis via DNA-PK and Akt. Nat Med. 2015; 21:906-913. [PubMed: 26107252]

169. Chen IF, Ou-Yang F, Hung JY, Liu JC, Wang H, Wang SC, Hou MF, Hortobagyi GN, Hung MC. AIM2 suppresses human breast cancer cell proliferation in vitro and mammary tumor growth in a mouse model. Mol Cancer Ther. 2006; 5:1-7. [PubMed: 16432157]

170. Kayagaki N, Warming S, Lamkanfi M, Vande Walle L, Louie S, Dong J, Newton K, Qu Y, Liu J, Heldens S, Zhang J, Lee WP, Roose-Girma M, Dixit VM. Non-canonical inflammasome activation targets caspase-11. Nature. 2011; 479:117-121. [PubMed: 22002608]

171. Hagar JA, Powell DA, Aachoui Y, Ernst RK, Miao EA. Cytoplasmic LPS activates caspase-11: implications in TLR4-independent endotoxic shock. Science. 2013; 341:1250-1253. [PubMed: 24031018]

172. Kayagaki N, Wong MT, Stowe IB, Ramani SR, Gonzalez LC, Akashi-Takamura S, Miyake K, Zhang J, Lee WP, Muszynski A, Forsberg LS, Carlson RW, Dixit VM. Noncanonical inflammasome activation by intracellular LPS independent of TLR4. Science. 2013; 341:12461249. [PubMed: 23887873]

173. Shi J, Zhao Y, Wang Y, Gao W, Ding J, Li P, Hu L, Shao F. Inflammatory caspases are innate immune receptors for intracellular LPS. Nature. 2014; 514:187-192. [PubMed: 25119034]

174. Zanoni I, Tan Y, Di Gioia M, Broggi A, Ruan J, Shi J, Donado CA, Shao F, Wu H, Springstead JR, Kagan JC. An endogenous caspase-11 ligand elicits interleukin-1 release from living dendritic cells. Science. 2016; 352:1232-1236. [PubMed: 27103670]

175. Kayagaki N, Stowe IB, Lee BL, O’Rourke K, Anderson K, Warming S, Cuellar T, Haley B, Roose-Girma M, Phung QT, Liu PS, Lill JR, Li H, Wu J, Kummerfeld S, Zhang J, Lee WP, Snipas SJ, Salvesen GS, Morris LX, Fitzgerald L, Zhang Y, Bertram EM, Goodnow CC, Dixit VM. Caspase-11 cleaves gasdermin D for non-canonical inflammasome signalling. Nature. 2015; 526:666-671. [PubMed: 26375259]

176. Shi J, Zhao Y, Wang K, Shi X, Wang Y, Huang H, Zhuang Y, Cai T, Wang F, Shao F. Cleavage of GSDMD by inflammatory caspases determines pyroptotic cell death. Nature. 2015; 526:660 665. [PubMed: 26375003] 
177. Vigano E, Diamond CE, Spreafico R, Balachander A, Sobota RM, Mortellaro A. Human caspase-4 and caspase-5 regulate the one-step non-canonical inflammasome activation in monocytes. Nat Commun. 2015; 6:8761. [PubMed: 26508369]

178. Allen IC, TeKippe EM, Woodford RM, Uronis JM, Holl EK, Rogers AB, Herfarth HH, Jobin C, Ting JP. The NLRP3 inflammasome functions as a negative regulator of tumorigenesis during colitis-associated cancer. J Exp Med. 2010; 207:1045-1056. [PubMed: 20385749]

179. Zaki MH, Boyd KL, Vogel P, Kastan MB, Lamkanfi M, Kanneganti TD. The NLRP3 inflammasome protects against loss of epithelial integrity and mortality during experimental colitis. Immunity. 2010; 32:379-391. [PubMed: 20303296]

180. Dupaul-Chicoine J, Arabzadeh A, Dagenais M, Douglas T, Champagne C, Morizot A, RodrigueGervais IG, Breton V, Colpitts SL, Beauchemin N, Saleh M. The Nlrp3 Inflammasome Suppresses Colorectal Cancer Metastatic Growth in the Liver by Promoting Natural Killer Cell Tumoricidal Activity. Immunity. 2015; 43:751-763. [PubMed: 26384545]

181. Bauer C, Duewell P, Mayer C, Lehr HA, Fitzgerald KA, Dauer M, Tschopp J, Endres S, Latz E, Schnurr M. Colitis induced in mice with dextran sulfate sodium (DSS) is mediated by the NLRP3 inflammasome. Gut. 2010; 59:1192-1199. [PubMed: 20442201]

182. Okamoto M, Liu W, Luo Y, Tanaka A, Cai X, Norris DA, Dinarello CA, Fujita M. Constitutively Active Inflammasome in Human Melanoma Cells Mediating Autoinflammation via Caspase-1 Processing and Secretion of Interleukin-1 $\beta^{*}$. J Biol Chem. 2010; 285:6477-6488. [PubMed: 20038581]

183. Verma D, Bivik C, Farahani E, Synnerstad I, Fredrikson M, Enerback C, Rosdahl I, Soderkvist P. Inflammasome polymorphisms confer susceptibility to sporadic malignant melanoma. Pigment Cell Melanoma Res. 2012; 25:506-513. [PubMed: 22524199]

184. Xu Y, Li H, Chen W, Yao X, Xing Y, Wang X, Zhong J, Meng G. Mycoplasma hyorhinis activates the NLRP3 inflammasome and promotes migration and invasion of gastric cancer cells. PLoS One. 2013; 8:e77955. [PubMed: 24223129]

185. Wei Q, Mu K, Li T, Zhang Y, Yang Z, Jia X, Zhao W, Huai W, Guo P, Han L. Deregulation of the NLRP3 inflammasome in hepatic parenchymal cells during liver cancer progression. Lab Invest. 2014; 94:52-62. [PubMed: 24166187]

186. Ghiringhelli F, Apetoh L, Tesniere A, Aymeric L, Ma Y, Ortiz C, Vermaelen K, Panaretakis T, Mignot G, Ullrich E, Perfettini JL, Schlemmer F, Tasdemir E, Uhl M, Genin P, Civas A, Ryffel B, Kanellopoulos J, Tschopp J, Andre F, Lidereau R, McLaughlin NM, Haynes NM, Smyth MJ, Kroemer G, Zitvogel L. Activation of the NLRP3 inflammasome in dendritic cells induces IL-1beta-dependent adaptive immunity against tumors. Nat Med. 2009; 15:1170-1178. [PubMed: 19767732]

187. van Deventer HW, Burgents JE, Wu QP, Woodford RM, Brickey WJ, Allen IC, McElvaniaTekippe E, Serody JS, Ting JP. The inflammasome component NLRP3 impairs antitumor vaccine by enhancing the accumulation of tumor-associated myeloid-derived suppressor cells. Cancer Res. 2010; 70:10161-10169. [PubMed: 21159638]

188. Carmi Y, Dotan S, Rider P, Kaplanov I, White MR, Baron R, Abutbul S, Huszar M, Dinarello CA, Apte RN, Voronov E. The role of IL-1beta in the early tumor cell-induced angiogenic response. J Immunol. 2013; 190:3500-3509. [PubMed: 23475218]

189. Tarassishin L, Lim J, Weatherly DB, Angeletti RH, Lee SC. Interleukin-1-induced changes in the glioblastoma secretome suggest its role in tumor progression. J Proteomics. 2014; 99:152-168. [PubMed: 24503185]

190. Hu B, Elinav E, Huber S, Booth CJ, Strowig T, Jin C, Eisenbarth SC, Flavell RA. Inflammationinduced tumorigenesis in the colon is regulated by caspase-1 and NLRC4. Proc Natl Acad Sci U S A. 2010; 107:21635-21640. [PubMed: 21118981]

191. Chen YK, Huse SS, Lin LM. Expression of inhibitor of apoptosis family proteins in human oral squamous cell carcinogenesis. Head Neck. 2011; 33:985-998. [PubMed: 20967871]

192. Choi J, Hwang YK, Choi YJ, Yoo KE, Kim JH, Nam SJ, Yang JH, Lee SJ, Yoo KH, Sung KW, Koo HH, Im YH. Neuronal apoptosis inhibitory protein is overexpressed in patients with unfavorable prognostic factors in breast cancer. J Korean Med Sci. 2007; 22(Suppl):S17-23. [PubMed: 17923748] 
193. Krajewska M, Krajewski S, Banares S, Huang X, Turner B, Bubendorf L, Kallioniemi OP, Shabaik A, Vitiello A, Peehl D, Gao GJ, Reed JC. Elevated expression of inhibitor of apoptosis proteins in prostate cancer. Clin Cancer Res. 2003; 9:4914-4925. [PubMed: 14581366]

194. McConnell BB, Vertino PM. TMS1/ASC: the cancer connection. Apoptosis. 2004; 9:5-18. [PubMed: 14739594]

195. Levine JJ, Stimson-Crider KM, Vertino PM. Effects of methylation on expression of TMS1/ASC in human breast cancer cells. Oncogene. 2003; 22:3475-3488. [PubMed: 12776200]

196. Yokoyama T, Sagara J, Guan X, Masumoto J, Takeoka M, Komiyama Y, Miyata K, Higuchi K, Taniguchi S. Methylation of ASC/TMS1, a proapoptotic gene responsible for activating procaspase-1, in human colorectal cancer. Cancer Lett. 2003; 202:101-108. [PubMed: 14643031]

197. Das PM, Ramachandran K, Vanwert J, Ferdinand L, Gopisetty G, Reis IM, Singal R. Methylation mediated silencing of TMS1/ASC gene in prostate cancer. Mol Cancer. 2006; 5:28. [PubMed: 16848908]

198. Machida EO, Brock MV, Hooker CM, Nakayama J, Ishida A, Amano J, Picchi MA, Belinsky SA, Herman JG, Taniguchi S, Baylin SB. Hypermethylation of ASC/TMS1 is a sputum marker for late-stage lung cancer. Cancer Res. 2006; 66:6210-6218. [PubMed: 16778195]

199. Stone AR, Bobo W, Brat DJ, Devi NS, Van Meir EG, Vertino PM. Aberrant methylation and down-regulation of TMS1/ASC in human glioblastoma. Am J Pathol. 2004; 165:1151-1161. [PubMed: 15466382]

200. Liu W, Luo Y, Dunn JH, Norris DA, Dinarello CA, Fujita M. Dual role of apoptosis-associated speck-like protein containing a CARD (ASC) in tumorigenesis of human melanoma. J Invest Dermatol. 2013; 133:518-527. [PubMed: 22931929]

201. Heneka MT, Kummer MP, Stutz A, Delekate A, Schwartz S, Saecker A, Griep A, Axt D, Remus A, Tzeng TC, Gelpi E, Halle A, Korte M, Latz E, Golenbock D. NLRP3 is activated in Alzheimer's disease and contributes to pathology in APP/PS1 mice. Nature. 2013; 493:674-678. [PubMed: 23254930]

202. Gris D, Ye Z, Iocca HA, Wen H, Craven RR, Gris P, Huang M, Schneider M, Miller SD, Ting JP. NLRP3 plays a critical role in the development of experimental autoimmune encephalomyelitis by mediating Th1 and Th17 responses. J Immunol. 2010; 185:974-981. [PubMed: 20574004]

203. Jha S, Ting JP. Inflammasome-associated nucleotide-binding domain, leucine-rich repeat proteins and inflammatory diseases. J Immunol. 2009; 183:7623-7629. [PubMed: 20007570]

204. Inoue M, Williams KL, Oliver T, Vandenabeele P, Rajan JV, Miao EA, Shinohara ML. IFN-beta therapy against EAE is effective only when development of the disease depends on the NLRP3 inflammasome. Sci Signal. 2012; 5:ra38. [PubMed: 22623753]

205. Kimkong I, Avihingsanon Y, Hirankarn N. Expression profile of HIN200 in leukocytes and renal biopsy of SLE patients by real-time RT-PCR. Lupus. 2009; 18:1066-1072. [PubMed: 19762380]

206. Wozniacka A, Lesiak A, Narbutt J, McCauliffe DP, Sysa-Jedrzejowska A. Chloroquine treatment influences proinflammatory cytokine levels in systemic lupus erythematosus patients. Lupus. 2006; 15:268-275. [PubMed: 16761500] 


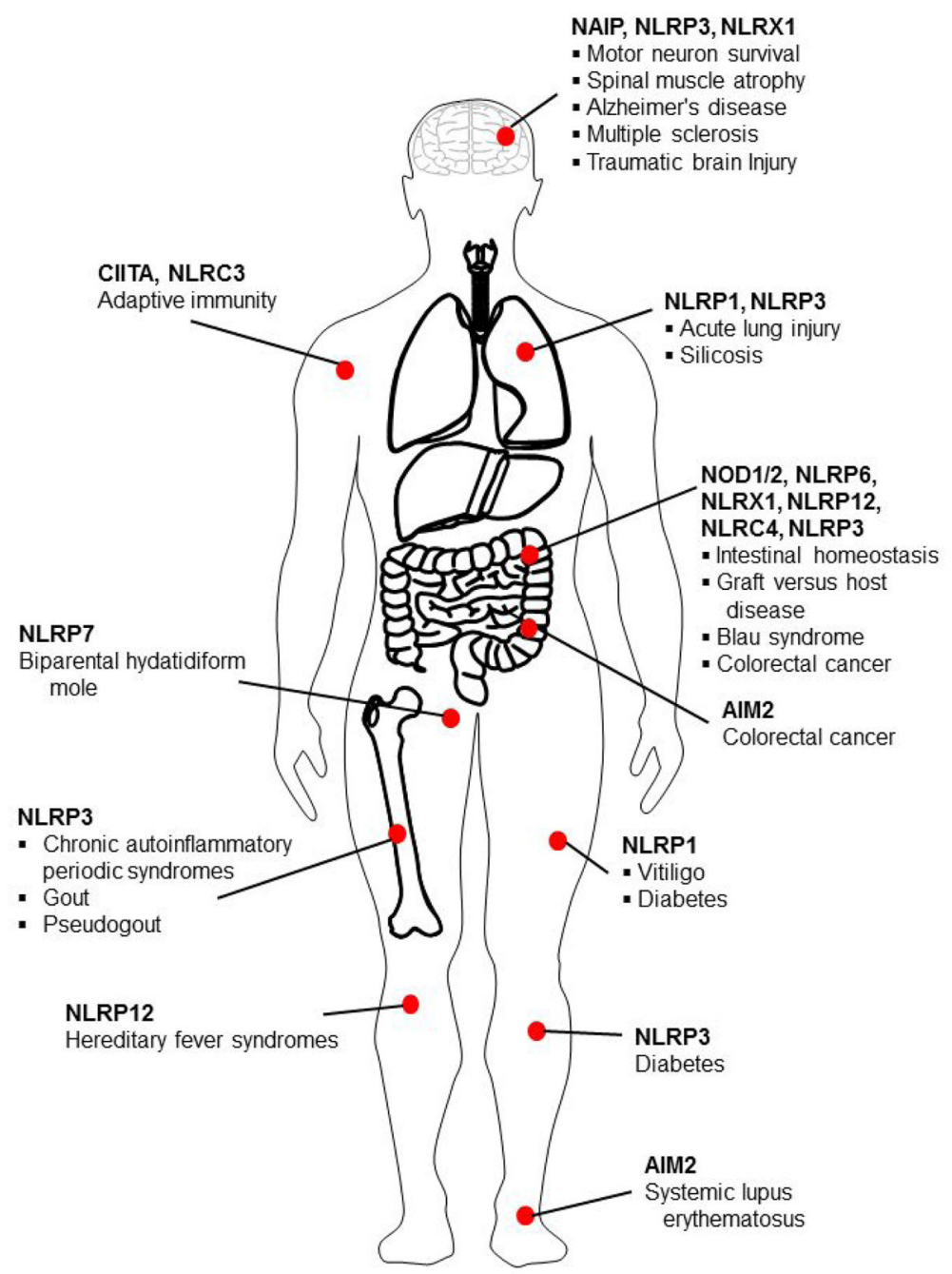

Figure 1. NLRs function in healthy and dysregulated disease states in the human body NLRs recognized to be involved in various healthy or disease states are shown. 


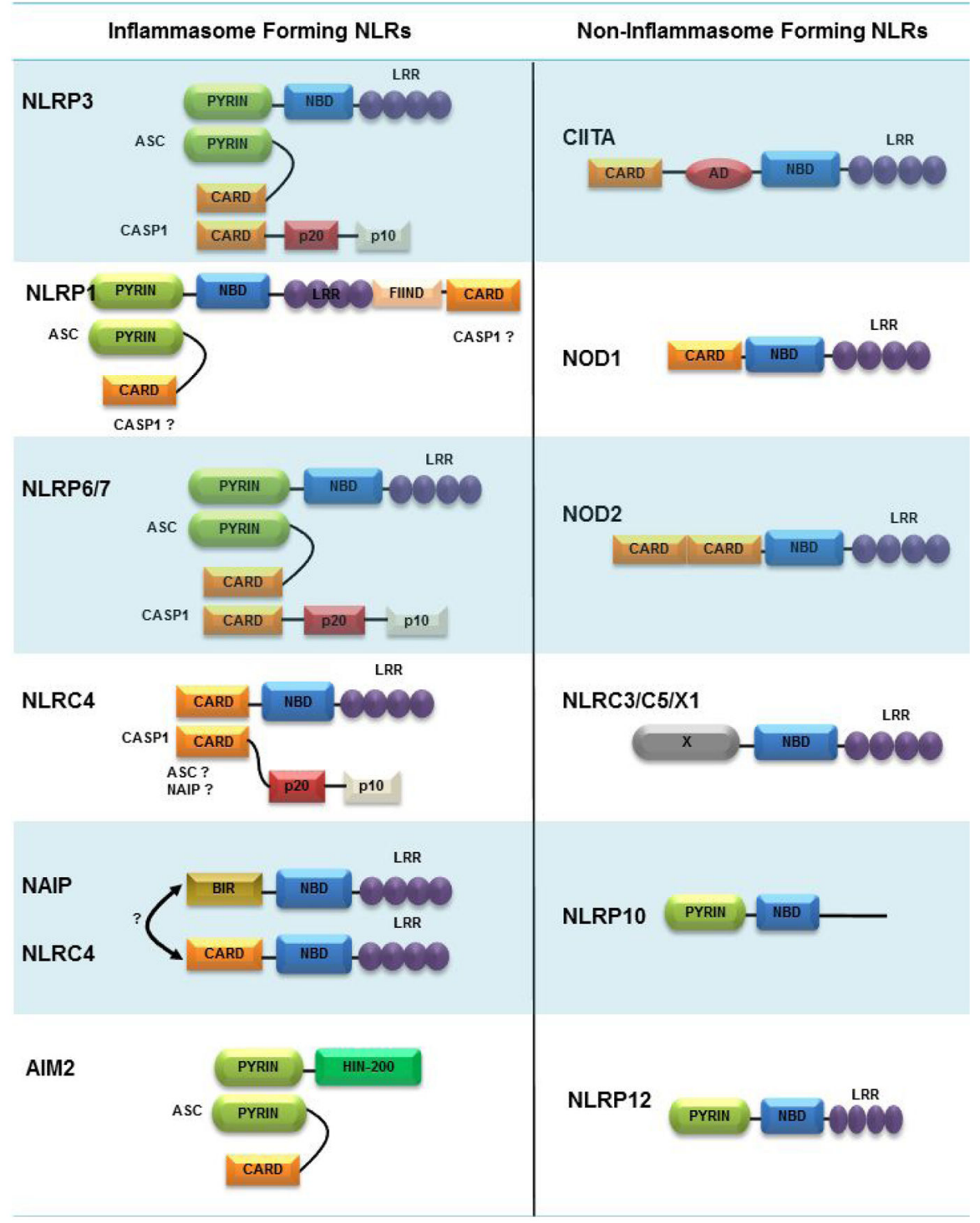

Figure 2. NLRs have a conserved tripartite structure and some form inflammasomes NLRs have a conserved tripartite structure with an N-terminal effector domain, a central nucleotide binding domain (NBD) and C-terminal leucine rich repeats (LRR). The effector domains of NLRs may include: acidic transactivation domain (AD), baculoviral inhibitory repeat (BIR)-like domain, caspase recruitment domain (CARD), pyrin domain or domain of unknown function (X). In general, NLRP1, NLRP3, NLRP6, NLRP7, NLRC4, NAIP and AIM2 are known to form inflammasomes, while CIITA, NOD1, NOD2, NLRC3, NLRC5, NLRX1, NLRP10 and NLRP12 do not. 


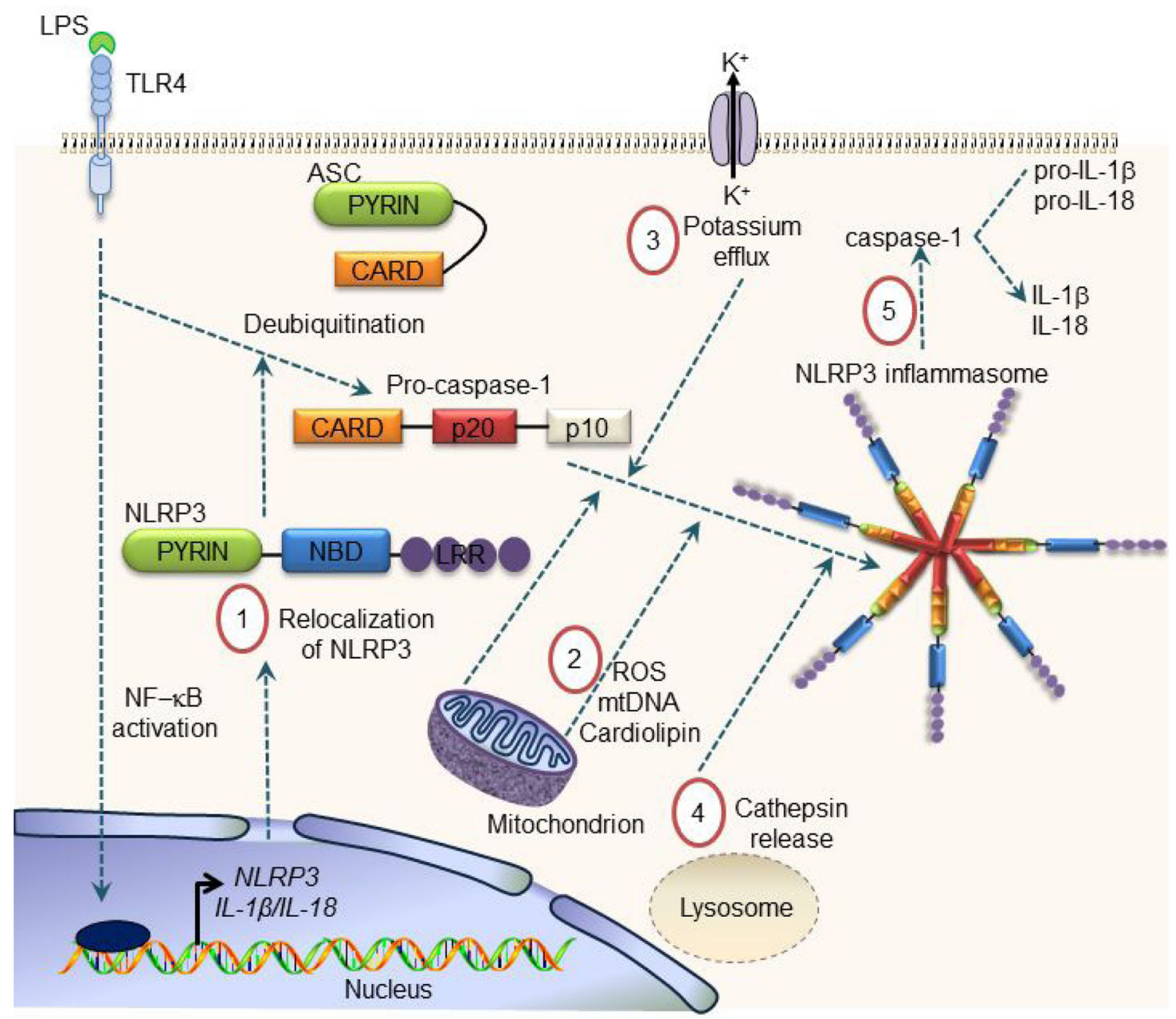

Figure 3. NLRP3 inflammasome is activated in response to multiple signals

The NLRP3 inflammasome is activated in response to several PAMPs and DAMPs including, but not limited to nucleic acids, lipopolysaccharide (LPS), lipooligosaccharide (LOS), muramyl dipeptide (MDP), ATP, uric acid crystals, hyaluronan sulfate, heparin sulfate, $\beta$-amyloid, asbestos and silica. NLRP3 inflammasome formation is a two signal process. The first signal involves priming: LPS engagement of TLR4 leads to NF- $\kappa \mathrm{B}$ activation causing increased expression of NLRP3 and IL-1 $\beta$ (Step-1). NLRP3 forms a multi-protein inflammasome complex with the adaptor apoptosis-associated speck-like protein containing a CARD (ASC) and pro-caspase-1. NLRP3 and ASC undergo deubiquitination prior to inflammasome assembly. After priming, canonical inflammasome activation requires a second signal. The second signal may be the release of mitochondrial factors into the cytoplasm such as ROS, mitochondrial DNA (mtDNA), or cardiolipin (Step-2), potassium efflux (Step-3) or lysosomal cathepsin release (Step-4). After receiving the second signal, NLRP3 recruits ASC via pyrin-pyrin interactions. ASC utilizes its CARD domain to recruit pro-caspase-1 by CARD-CARD interactions, thus leading to processing of pro-caspase-1 to active caspase-1 (Step-5). In turn, caspase-1 is critical for the processing 
and release of IL-1 $\beta$ and IL-18. We gratefully acknowledge the support of National Institutes of Health funding (U19-AI109965 and U19-AI067798) to JPYT and WJB. 